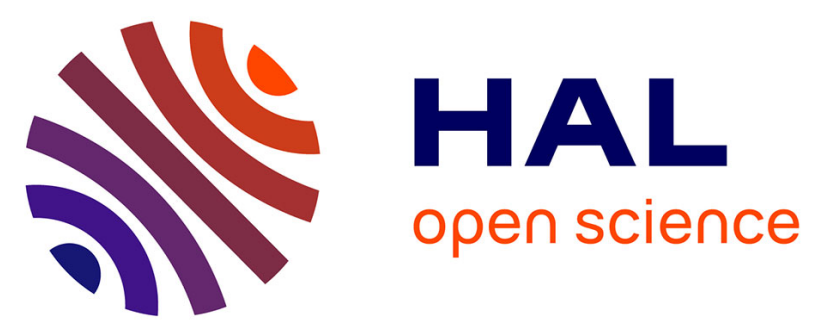

\title{
Endoplasmic reticulum calcium release potentiates the ER stress and cell death caused by an oxidative stress in MCF-7 cells
}

\author{
Nicolas Dejeans, Nicolas Tajeddine, Raphaël Beck, Julien Verrax, Henryk \\ Taper, Philippe Gailly, Pedro Buc Calderon
}

\section{To cite this version:}

Nicolas Dejeans, Nicolas Tajeddine, Raphaël Beck, Julien Verrax, Henryk Taper, et al.. Endoplasmic reticulum calcium release potentiates the ER stress and cell death caused by an oxidative stress in MCF-7 cells. Biochemical Pharmacology, 2010, 79 (9), pp.1221. 10.1016/j.bcp.2009.12.009 . hal00573895

\section{HAL Id: hal-00573895 \\ https://hal.science/hal-00573895}

Submitted on 5 Mar 2011

HAL is a multi-disciplinary open access archive for the deposit and dissemination of scientific research documents, whether they are published or not. The documents may come from teaching and research institutions in France or abroad, or from public or private research centers.
L'archive ouverte pluridisciplinaire HAL, est destinée au dépôt et à la diffusion de documents scientifiques de niveau recherche, publiés ou non, émanant des établissements d'enseignement et de recherche français ou étrangers, des laboratoires publics ou privés. 


\section{Accepted Manuscript}

Title: Endoplasmic reticulum calcium release potentiates the ER stress and cell death caused by an oxidative stress in MCF-7 cells

Authors: Nicolas Dejeans, Nicolas Tajeddine, Raphaël Beck, Julien Verrax, Henryk Taper, Philippe Gailly, Pedro Buc

Calderon

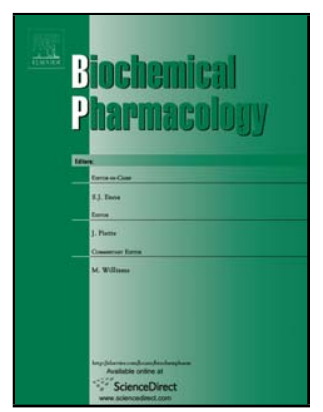

PII:

S0006-2952(09)01067-3

DOI: doi:10.1016/j.bcp.2009.12.009

Reference: BCP 10406

To appear in: $\quad B C P$

Received date: $\quad$ 28-10-2009

Revised date: 4-12-2009

Accepted date: $\quad$ 7-12-2009

Please cite this article as: Dejeans N, Tajeddine N, Beck R, Verrax J, Taper H, Gailly $\mathrm{P}$, Calderon PB, Endoplasmic reticulum calcium release potentiates the ER stress and cell death caused by an oxidative stress in MCF-7 cells, Biochemical Pharmacology (2008), doi:10.1016/j.bcp.2009.12.009

This is a PDF file of an unedited manuscript that has been accepted for publication. As a service to our customers we are providing this early version of the manuscript. The manuscript will undergo copyediting, typesetting, and review of the resulting proof before it is published in its final form. Please note that during the production process errors may be discovered which could affect the content, and all legal disclaimers that apply to the journal pertain. 


\section{Endoplasmic reticulum calcium release potentiates the ER stress}

\section{and cell death caused by an oxidative stress in MCF-7 cells}

Nicolas Dejeans ${ }^{\text {a }}$, Nicolas Tajeddine ${ }^{\text {b }}$, Raphaël Beck ${ }^{\text {a }}$, Julien Verrax ${ }^{\text {a }}$, Henryk Taper

${ }^{a \dagger}$, Philippe Gailly ${ }^{\text {b }}$, Pedro Buc Calderon ${ }^{\text {a,c,* }}$.

${ }^{a}$ Université Catholique de Louvain, Louvain Drug Research Institute, Toxicology and Cancer

Biology Research Group, PMNT Unit, Belgium

${ }^{b}$ Université Catholique de Louvain, Laboratory of Cell Physiology, Belgium.

${ }^{c}$ Departamento de Ciencias Quimicas y Farmaceuticas, Universidad Arturo Prat, Iquique,

Chile.

${ }^{\dagger}$ Died the 4th of April, 2009.

Running title: calcium and oxidative stress in cancer cell death

* Corresponding author. Pedro Buc Calderon, avenue E. Mounier 73, 1200 Bruxelles,

Belgium, Phone: +32 276473 66, Fax: +32 27647359

E-mail: pedro.buccalderon@uclouvain.be 


\section{ABSTRACT}

Increase in cytosolic calcium concentration $\left(\left[\mathrm{Ca}^{2+}\right]_{\mathrm{c}}\right)$, release of endoplasmic reticulum (ER) calcium $\left(\left[\mathrm{Ca}^{2+}\right]_{\mathrm{er}}\right)$ and ER stress have been proposed to be involved in oxidative toxicity. Nevertheless, their relative involvements in the processes leading to cell death are not well defined. In this study, we investigated whether oxidative stress generated during ascorbatedriven menadione redox cycling (Asc/Men) could trigger these three events, and, if so, whether they contributed to Asc/Men cytoxicity in MCF-7 cells. Using microspectrofluorimetry, we demonstrated that Asc/Men-generated oxidative stress was associated with a slow and moderate increase in $\left[\mathrm{Ca}^{2+}\right]_{c}$, largely preceding permeation of propidium iodide, and thus cell death. Asc/Men treatment was shown to partially deplete ER calcium stores after 90 min (decrease by $45 \%$ compared to control). This event was associated with ER stress activation, as shown by analysis of eIF2 phosphorylation and expression of the molecular chaperone GRP94. Thapsigargin (TG) was then used to study the effect of complete $\left[\mathrm{Ca}^{2+}\right]_{\mathrm{er}}$ emptying during the oxidative stress generated by Asc/Men. Surprisingly, the combination of TG and Asc/Men increased ER stress to a level considerably higher than that observed for either treatment alone, suggesting that $\left[\mathrm{Ca}^{2+}\right]_{\mathrm{er}}$ release alone is not sufficient to explain ER stress activation during oxidative stress. Finally, TG-mediated $\left[\mathrm{Ca}^{2+}\right]_{\mathrm{er}}$ release largely potentiated ER stress, DNA fragmentation and cell death caused by Asc/Men, supporting a role of ER stress in the process of Asc/Men cytotoxicity. Taken together, our results highlight the involvement of ER stress and $\left[\mathrm{Ca}^{2+}\right]_{\mathrm{er}}$ decrease in the process of oxidative stress-induced cell death in MCF-7 cells.

KEYWORDS: Oxidative stress, Breast cancer, Calcium homeostasis, Endoplasmic reticulum stress, MCF-7 cells, Ascorbate-driven menadione redox cycling. 


\section{Introduction}

It has long been known that disruption of intracellular calcium homeostasis is one of the primary processes in the early development of cell injury [1-3] and that elevation of intracellular calcium levels can provoke a switch from normal regulation of cell function to a signal for cell death [3]. Different mechanisms have been implicated in this phenomenon, including activation of calcium-dependent proteases (i.e., calpains), calmodulin-associated enzymes (i.e., the phosphatase and regulator calcineurin), and calcium-dependent endonucleases or apoptotic pathways associated with perturbations in mitochondrial calcium concentrations [3-5]. In oxidative stress, intracellular calcium deregulation has been shown to have a central role in the induction of apoptosis or necrosis [5].

Endoplasmic reticulum (ER) stress is an essential adaptive cell response to the accumulation of misfolded proteins and is induced by the quality control system that ensures the transit of correctly folded proteins to the Golgi [6]. The primary role of ER stress is to favor cell survival by increasing the capacity to fold or refold proteins or by facilitating the export of misfolded proteins to the cytosol and their subsequent degradation (ER-associated degradation or ERAD) [6]. This phenomenon requires a complex regulatory process, known as the unfolded protein response (UPR), which regulates the transcription and translation of a great number of genes [7]. This process can finally induce cell death, probably when the initial survival response cannot counteract the protein modifications [6]. The molecular processes of ER stress-induced cell death represent a promising research area as this event may be involved in the physiopathology of atherosclerosis, diabetes and cancer, diseases known to be closely linked to oxidative stress [8]. In tumors, UPR is activated in response to the microenvironment, generally hypoxic and low in energy. Thus, some ER chaperones 
appear to be potential biomarkers for tumor behavior and resistance to cancer therapies [8-10] and some researchers have proposed that ER stress proteins should be targeted to potentiate cancer treatments $[9,10]$.

Cells exposed to oxidative injury have various ER stress inducing factors [11]. Indeed, previous reports showed that oxidants can release ER calcium $\left(\left[\mathrm{Ca}^{2+}\right]_{\mathrm{er}}\right)[5,12-14]$ (presumably by inhibition of sarcoplasmic calcium ATPase $[15,16])$; this could represent a first mechanism by which oxidative injury can cause ER stress. Another possibility is that reactive oxygen species (ROS) may cause ER stress through generation and accumulation of oxidized proteins $[11,17]$. The ER appears to be particularly sensitive to such modifications [18-21], as its molecular environment has a high oxidizing redox potential, specialized in protein folding and disulfide bond formation [18, 22, 23]. Finally, ROS could directly damage proteins of the ER folding machinery, such as ER chaperones, and induce an accumulation of misfolded proteins and consequent UPR activation. Despite these data, research on the involvement of ER stress in the cellular response to ROS exposure is only emerging [11]. Few authors have reported UPR activation during oxidative stress and even fewer have demonstrated a direct involvement of ER stress in oxidative toxicity [19, 24-28]. In summary, ER homeostasis is a fragile equilibrium, which can be modulated by dysregulation of calcium or oxidative/reductive balance, features previously associated with oxidative stress. However, studies of the links between these factors are scarce.

We and others have shown that the association of ascorbate and menadione is an $\mathrm{H}_{2} \mathrm{O}_{2-}$ generating system that results in necrosis-like cell death in a wide variety of cancer cell types [29-35] including MCF-7 cells (a human breast derived cell line), and that loss of calcium homeostasis appeared to be a major factor in the cytotoxicity [36]. The aim of the present study was to investigate the role of disruption of calcium homeostasis and a potential involvement of ER stress in the mechanisms leading to cancer cell death from an oxidative 
stress. Using MCF-7 cells, we showed that 1) oxidative stress caused a slow increase in $\left[\mathrm{Ca}^{2+}\right]_{\mathrm{c}}$ concentration in MCF-7 cells; 2) this increase in $\left[\mathrm{Ca}^{2+}\right]_{\mathrm{c}}$ appeared not to be associated with oxidative stress cytotoxic pathways; 3 ) oxidative stress led to a partial release of $\left[\mathrm{Ca}^{2+}\right]_{\mathrm{er}}$; 4) calcium release was not the main causative factor in ER stress triggered by oxidative conditions; and 5) $\left[\mathrm{Ca}^{2+}\right]_{\mathrm{er}}$ release potentiated oxidative stress induced cell death.

\section{Materials and methods}

\subsection{Chemicals}

Menadione sodium bisulfite (Men), sodium ascorbate (Asc), N-acetylcysteine (NAC), BAPTA-AM, dimethylsulfoxide (DMSO), EGTA, ionomycin and W-7 hydrochloride were purchased from Sigma-Aldrich (St. Louis, MO). Thapsigargin (TG), aurintricarboxylic acid (ATA) and cyclosporine A (CsA) were purchased from Santa Cruz Biotechnology (Santa Cruz, CA), Calpeptin (Calp) and Ru360 from Calbiochem (San Diego, CA), fluo-3/AM from Tebu-Bio (Boechout, BE), fura-2, AM from Molecular Probes (Eugene, OR), Iodoacetate from Acros Organics (Geel, BE) and propidium iodide from Roche Diagnostics Corp (Indianapolis, IN). All other chemicals were ACS reagent grade.

\section{2. $\quad$ Cell Culture and Treatments}

The MCF-7 cell line was a gift from Dr. F. Brasseur (Ludwig Institute for Cancer Research, LICR-Brussels). The cells were cultured in DMEM (Dulbecco's modified eagle medium, (Gibco BRL, Life Technologies, Merelbeke, BE)) supplemented with $10 \%$ fetal calf serum, penicillin $(10000 \mathrm{U} / \mathrm{ml})$, streptomycin $(10 \mathrm{mg} / \mathrm{ml})$ and $1.2 \%$ glutamine. The cultures were maintained at a density of about $50 \times 10^{3}$ cells $/ \mathrm{cm}^{2}$. The medium was changed at $48-72 \mathrm{~h}$ intervals. All cultures were maintained at $37^{\circ} \mathrm{C}$ in $95 \%$ air $/ 5 \% \mathrm{CO} 2$ with $100 \%$ humidity. For each passage, cells were washed twice with PBS (Gibco) and then incubated at $37^{\circ} \mathrm{C}$ with $0.25 \%$ trypsin-EDTA (Sigma-Aldrich, St Louis, MO). Cultures were treated with 1 or $0.5 \mathrm{mM}$ 
sodium ascorbate and 10 or $5 \mu \mathrm{M}$ menadione bisulfite as the $\mathrm{H}_{2} \mathrm{O}_{2}$-generating system. When indicated, the antioxidant NAC was added to cell cultures at a concentration of $3 \mathrm{mM}$ for 15 minutes before the addition of ascorbate and menadione. Cells were incubated with TG or iodoacetate at concentrations of 1 and $100 \mu \mathrm{M}$, respectively, to induce ER calcium release or glycolysis arrest, respectively.

\subsection{Cell survival measurement}

The effects of Asc/Men and TG on MCF-7 cell survival were monitored by the erythrosine exclusion assay. Cells were seeded onto 6-well plates at a density of 300000 cells/well for 24 $\mathrm{h}$ and then incubated for different durations in the absence or presence of the various compounds. Cells were then gently washed with $1 \mathrm{ml}$ PBS, harvested using trypsin-EDTA solution, collected and mixed with $100 \mu \mathrm{l}$ of medium. Then, $900 \mu \mathrm{l}$ of a solution containing $0.9 \% \mathrm{NaCl}$ and $0.4 \%$ erythosin $(\mathrm{w} / \mathrm{v})$ was added, the solution was gently mixed and nonerythrosine positive cells were immediately counted microscopically using a Burker chamber.

\subsection{MTT assay}

The effects of Asc/Men, TG or iodoacetate on cell metabolic status were assessed by following the reduction of MTT (3-(4,5-dimethylthiazolyl-2)-2,5-diphenyltetrazolium bromide) to blue formazan [37]. Briefly, cells were seeded into 96-well plates at a density of 10000 cells/well for $24 \mathrm{~h}$ and then incubated for different durations in the absence or in the presence of the various compounds ( 8 wells were used for each condition). Cells were then washed with PBS and incubated with MTT $(0.5 \mathrm{mg} / \mathrm{ml})$ for $2 \mathrm{~h}$ at $37^{\circ} \mathrm{C}$. Blue formazan crystals were solubilized by adding $100 \mu \mathrm{DMSO} /$ well, and the colored solution was subsequently read at $550 \mathrm{~nm}$. Results are expressed as \% of MTT reduction compared to untreated control conditions.

\subsection{ATP measurements}


The ATP content was assessed using the bioluminescence kit ATPLite (Perkin Elmer, Zaventem, BE) according to the procedure provided by the manufacturer. Results are expressed as $\mathrm{nmol} / 10^{6}$ cells.

\subsection{Immunoblotting assays}

At the indicated times, cells were washed twice with ice-cold PBS and then resuspended in an RIPA lysis buffer supplemented with 1\% Protease Inhibitor Cocktail (Sigma-Aldrich) and 3\% Phosphatase Inhibitor Cocktail (Calbiochem). The samples were kept on ice for $5 \mathrm{~min}$. They were then centrifuged at $13,000 \times \mathrm{g}$ for $15 \mathrm{~min}$ at $4^{\circ} \mathrm{C}$ or sonicated for 15 seconds for the detection of $\gamma-\mathrm{H} 2 \mathrm{AX}$. Supernatants or sonicated samples were collected and then stored at $-80^{\circ} \mathrm{C}$. Equal amounts of proteins were subjected to SDS-PAGE (6-15\% separating gel) followed by electroblot to nitrocellulose membranes. The membranes were blocked for 1 hour in TBS buffer ( $\mathrm{pH} 7.4)$ containing 5\% powdered milk protein and then incubated overnight at $4^{\circ} \mathrm{C}$ with the appropriate antibody. Antibody against PAR was obtained from BD Biosciences Pharmingen (Franklin Lakes, NJ). Rabbit polyclonal antibody against phospho-H2AX ( $\gamma$ H2AX) was from Upstate (Billerica, MA), against GRP94 from Chemicon International (Temecula, CA), and against Phospho-eIF2a (Ser51) from Cell Signaling Technology (Danvers, MA). After washing, membranes were exposed for $60 \mathrm{~min}$ at room temperature to a secondary antibody from Chemicon International (Temecula, CA) linked to HRP or alkaline phosphatase. Finally, the protein bands were detected by chemiluminescence.

\section{7. $\left[\mathrm{Ca}^{2+}\right]_{c}$ measurements by microspectrofluorimetry}

Measurement of $\left[\mathrm{Ca}^{2+}\right]_{\mathrm{c}}$ was performed as previously described [38] with some modifications. The cells, plated on glass coverslips, were incubated with $1 \mu \mathrm{M}$ fura- $2 \mathrm{AM}$ in medium at $37^{\circ} \mathrm{C}$ for $30 \mathrm{~min}$, then washed for $10 \mathrm{~min}$ in $\mathrm{HBSS}$ at $20^{\circ} \mathrm{C}$ and maintained at room temperature in the same saline solution until the fluorescence was measured. The coverslip was then mounted in a Pecon microscope chamber $(1 \mathrm{ml})$. When indicated, cells were 
superfused with HBSS without calcium and with $200 \mu \mathrm{M}$ EGTA ( 1 ml. minute $\left.{ }^{-1}\right)$ allowing quick changes of extracellular solution. Fura-2 loaded cells were alternately excited at 340 and $380 \mathrm{~nm}$ using a Lambda DG-4 Ultra High Speed Wavelength Switcher (Sutter Instrument, Novato, CA) coupled to a Zeiss Axivert 200M inverted microscope (x 20 fluorescence objective) (Zeiss Belgium, Zaventem, BE). Images were acquired every second at different times with a Zeiss Axiocam camera coupled with a $510 \mathrm{~nm}$ emission filter and analyzed by the Axiovision software. Fluorescence intensity was recorded over the entire surface of each cell and intracellular calcium concentration was evaluated from the ratio of the fluorescence emission intensities excited at the two wavelengths. Calibration of fura- 2 was performed as described by Palmer et al., [39] except that cells were treated with $10 \mu \mathrm{M}$ ionomycin and $10 \mathrm{mM}$ EGTA in $\mathrm{Ca}^{2+}$-free HBSS to obtain $\mathrm{Rmin}$ and with $20 \mathrm{mM} \mathrm{Ca}^{2+}$ in HBSS to obtain Rmax. The standard equation: $\mathrm{K}_{\mathrm{d}}[(\mathrm{R}-\mathrm{Rmin}) /(\mathrm{Rmax}-\mathrm{R})] \cdot \mathrm{S}_{\mathrm{f}} / \mathrm{S}_{\mathrm{b}}$ was used to convert the fura- 2 ratio to $\left[\mathrm{Ca}^{2+}\right]_{\mathrm{c}}$, where $\mathrm{S}_{\mathrm{f}}$ and $\mathrm{S}_{\mathrm{b}}$ are the emission intensities at $380 \mathrm{~nm}$ for $\mathrm{Ca}^{2+}$-free and $\mathrm{Ca}^{2+}$-bound fura-2, respectively. In situ $\mathrm{Rmin}$ and $\mathrm{Rmax}$ values were multiplied by 0.85 to adjust for the minimum viscosity effect.

\section{8. $\left[\mathrm{Ca}^{2+}\right]_{\mathrm{c}}$ measurements using a fluorescence microplate reader}

This method was adapted from the article by Robinson et al., [40]. For $\left[\mathrm{Ca}^{2+}\right]_{\mathrm{c}}$ measurement, MCF-7 cells were seeded onto 96-well plates at a density of 25000 cells/well in $100 \mu 1$ of growth media. At subconfluence, the culture medium was replaced with FBS free media for $24 \mathrm{~h}$ to attempt to synchronize cells into a nonproliferative stage. MCF-7 cells were then loaded with $25 \mu \mathrm{M}$ fluo-3/AM in medium at $37^{\circ} \mathrm{C}$ for $30 \mathrm{~min}$ followed by $30 \mathrm{~min}$ at room temperature to minimize dye leakage and sequestration into intracellular organelles. After loading, cells were washed twice with $200 \mu \mathrm{HBSS}$ in order to remove excess fluorescent dye. Cells were then treated for different durations with various compounds in normal or calcium-free medium. Cells were washed twice with $200 \mu \mathrm{l}$ HBSS and then $100 \mu 1$ 
HBSS/well was added. The fluorescence intensity of fluo-3 was measured at an excitation wavelength of $485 \mathrm{~nm}$ and an emission wavelength of $520 \mathrm{~nm}$. Relative changes in calcium concentration using fluo-3 were determined by calculations of $\Delta \mathrm{F} / \mathrm{F} 0$, where $\Delta \mathrm{F} / \mathrm{F} 0=(\mathrm{Ft}-$ F0)/F0. Ft represents the fluorescence reading at each time point and F0 the initial fluorescence. For live-cell imaging, cells were seeded on a 4-well Lab-Tek chamber glass slide (Nunc, Naperville, IL), at a density of 50000 cells/well, cultured for 3 days, and treated as described for the quantification protocol.

\subsection{Oxyblot}

The immunoblot detection of carbonyl groups introduced into proteins by oxidative reactions was achieved using OxyBlot ${ }^{\mathrm{TM}}$ Protein Oxidation Detection Kit (Chemicon International, Temecula, CA, USA) according to the procedure provided by the manufacturer.

\subsection{Data analysis}

Results are expressed as means \pm standard deviation (SD). Differences among the experimental groups were analysed using one-way ANOVA followed, where appropriate, by a Tukey post-hoc test. These tests were performed using GraphPad Prism software (GraphPad Software San Diego, CA, USA). P values less than 0.05 were considered statistically significant.

\section{Results}

\subsection{Oxidative stress induces calcium increase in MCF-7 cells}

To investigate the acute effects of the pro-oxidant association of Asc/Men on $\left[\mathrm{Ca}^{2+}\right]_{\mathrm{c}}$ in $\mathrm{MCF}-$ 7 cells, fluo-3/AM loaded cells were exposed to Asc/Men for different time periods. The results presented in Fig. $1 A$ show that incubation with Asc/Men resulted in a slow increase in $\left[\mathrm{Ca}^{2+}\right]_{\mathrm{c}}$ in MCF-7 cells. Using microspectrofluorimetry with the ratiometric fluorescent probe, 
fura-2, AM, the increase in $\left[\mathrm{Ca}^{2+}\right]_{\mathrm{c}}$ was estimated to be close to $50 \%$ after $90 \mathrm{~min}$ (Fig. $1 \mathrm{~B}$ ). To verify whether the calcium mobilization was not due to membrane disruption, $\left[\mathrm{Ca}^{2+}\right]_{\mathrm{c}}$ and propidium iodide permeation were simultaneously measured after different durations of exposure to Asc/Men (Fig. 1C). This experiment revealed that calcium increase was triggered during the first hour of Asc/Men treatment and that, in contrast, propidium iodide uptake was observed after more than $4 \mathrm{~h}$. This clearly indicates that the increase in $\left[\mathrm{Ca}^{2+}\right]_{\mathrm{c}}$ largely preceded signs of cell death.

\section{2. [Ca2+]c increase is unlikely to be associated with activation of calcium-dependent death} pathways

Since Asc/Men triggered disruption of calcium homeostasis in MCF-7 cells, we then explored the influence of oxidative stress on different pathways associated with calcium disturbance. First, calcium itself may directly activate proteases (i.e., calpains) or calmodulin-associated enzymes, which may themselves be involved in the cytotoxic processes of oxidative stress. Moreover, perturbations of intracellular calcium can activate mitochondrial apoptotic pathways, including the opening of the mitochondrial permeability transition pore (mPTP). We therefore tested the influence of inhibitors of these pathways on the loss of cell viability observed after Asc/Men treatment. W7 $(25 \mu \mathrm{M})$, calpeptin $(10 \mu \mathrm{M}), \mathrm{Ru} 360(5 \mu \mathrm{M})$, and cyclosporine A $(5 \mu \mathrm{M})$ were chosen to inhibit calcium-dependent proteases, calmodulin, entry of calcium into the mitochondria, and mPTP opening, respectively ( $1 \mathrm{~h}$ pre-incubation). Unlike the antioxidant, NAC, none of these compounds had any protective effect on oxidative stress-mediated decrease in cell viability (Fig. $2 A$ and $B$ ). We also hypothesized that the DNA strand breaks induced by Asc/Men (as we have previously shown [31, 33]) could be the result of calcium-dependent endonuclease activation. To study this hypothesis, we tested the effects of $1 \mathrm{~h}$ pre-incubation with $100 \mu \mathrm{M}$ aurintricarboxylic acid (a calcium-dependent endonuclease inhibitor) on the loss of viability observed in MCF-7 cells after Asc/Men exposure; this 
inhibitor had no measurable effect (Fig. 2A). To examine whether extracellular calcium chelation or depletion could affect Asc/Men cytotoxicity, we then measured MCF-7 cell viability after $4 \mathrm{~h}$ of exposure to Asc/Men, in media with and without calcium, or with $2 \mathrm{mM}$ of the extracellular calcium chelator, EGTA (Fig. $2 C$ ). Results from this experiment demonstrated that extracellular calcium depletion or chelation had no protective effects against Asc/Men. Taken together, our results show that the increase in intracellular calcium after administration of Asc/Men is unlikely to be involved in the mechanisms leading to MCF-7 death.

\subsection{Effect of BAPTA-AM, an intracellular calcium chelator on Asc/Men cytotoxic pathways.}

An intracellular calcium chelator, BAPTA-AM, was also used to explore the importance of an increase in cytosolic calcium on the cytotoxic pathways of Asc/Men. In our model, this chelator appeared to have a broad protective action, as shown by its concentration-dependent protection against the decrease in cell viability induced by Asc/Men exposure (Fig. 3A). However, since BAPTA-AM has been previously shown to chelate iron, and potentially interferes with Fenton's reaction $[41,42]$, we decided to identify at what level BAPTA-AM acts. Our results reveals that BAPTA-AM could prevent against all features of Asc/Men cytotoxicity, including decreases in ATP, PARP activation, DNA fragmentation, ER stress and even protein oxidation (Fig. $3 B, C$ and $D$ ). This suggests that the protective effect of BAPTA-AM observed in our model is most probably mediated by its capacity to interfere with pro-oxidative mechanisms, rather than by its ability to chelate calcium.

\subsection{ATP decrease and calcium release in MCF-7 cells exposed to oxidative stress}

Oxidative stress usually induces a rapid and marked decrease in cellular ATP. Among the consequences of this effect, the decrease in ATP may also be associated with ATP-dependent calcium channel dysfunction, a process potentially involved in the increase in $\left[\mathrm{Ca}^{2+}\right]_{\mathrm{c}}$ observed in MCF-7 cells exposed to oxidative stress. We, therefore, decided to explore the 
potential links between ATP depletion and increase in $\left[\mathrm{Ca}^{2+}\right]_{\mathrm{c}}$ during Asc/Men treatment. As shown in Fig. 4A, Asc/Men treatment induced a fast and dramatic decrease in ATP in MCF-7 cells. The glycolysis inhibitor, iodoacetate, was then used to mimic the decrease in cellular ATP level observed during Asc/Men treatment. As shown in Fig. 4B, exposure to $100 \mu \mathrm{M}$ iodoacetate resulted in a reduction in ATP level from $20.6 \pm 0.8$ to $8.6 \pm 0.2 \mathrm{nmol} / 10^{6}$ cells after 90 min. This decrease in ATP was not accompanied by the same increase in $\left[\mathrm{Ca}^{2+}\right]_{\mathrm{c}}$ observed after 90 min of Asc/Men treatment (Fig. 4C), confirming that the large increase in calcium observed in oxidative stress exposed MCF-7 cells was not due to ATP depletion.

\subsection{Oxidative stress partially releases $\left[\mathrm{Ca}^{2+}\right]_{\text {er }}$ and induces ER stress in MCF-7 cells}

Since disturbance in cytosolic calcium is unlikely to be involved in the pathways leading to the loss of cell viability induced by Asc/Men, we further studied the effect of Asc/Mengenerated oxidative stress on the ER, the major cellular store of calcium. We first measured whether the response of MCF-7 cells to TG (TG irreversibly inhibits (sarco)endoplasmic reticulum $\mathrm{Ca}^{2+}$-ATPase (SERCA) and depletes ER calcium stores) could be altered by Asc/Men. To this end, untreated control cells (Fig. 5A) or cells pre-treated with Asc/Men for 90 min (Fig. 5B) were stimulated with TG $(1 \mu \mathrm{M})$ after extracellular calcium removal and $\left[\mathrm{Ca}^{2+}\right]_{\mathrm{c}}$ was measured. The results showed that the TG-driven increase in $\left[\mathrm{Ca}^{2+}\right]_{\mathrm{c}}$ was attenuated when cells were pre-treated with Asc/Men. Indeed, Fig. $5 C$ shows that the response to $\mathrm{TG}$ was decreased by approximately $45 \%(124.8 \pm 8.0 \mathrm{nM}$ for control and $68.9 \pm 4.7 \mathrm{nM}$ for Asc/Men conditions). These findings suggest that Asc/Men slowly depletes calcium from the ER. Second, since $\left[\mathrm{Ca}^{2+}\right]_{\text {er }}$ release can be both a cause and a consequence of ER stress, we explored whether ER stress was associated with Asc/Men treatment. We measured levels of eIF2 phosphorylation, a central component of the control arm of the UPR, and of GRP94 protein abundance, one of the major ER chaperones that are transcriptionally upregulated during ER stress. Fig. $5 D$ shows that $1 \mathrm{~h}$ of Asc/Men treatment induced eIF2 phosphorylation, 
which increased dramatically after 2 and $4 \mathrm{~h}$. The appearance of P-eIF2 was associated with the increase in GRP94 protein. These results clearly indicate that oxidative stress induces ER stress in MCF-7 cells, concomitant with ER calcium release.

\subsection{Involvement of ER calcium emptying in ER stress triggered by oxidative stress and cell death}

Our results confirm the observations that Asc/Men triggers ER stress and ER calcium release. We then decided to address the issue of whether TG-induced complete calcium release had a putative effect on the ER stress induction observed in cells exposed to Asc/Men (Fig. 6A). For this experiment, ascorbate and menadione were used at the lowest concentrations of $0.5 \mathrm{mM}$ and $5 \mu \mathrm{M}$, respectively. At this concentration, Asc/Men induced eIF2 phosphorylation after 2 $\mathrm{h}$ of treatment, while TG triggered this event after $0.5 \mathrm{~h}$ (Fig. $6 A$ ). Surprisingly, the combination of Asc/Men and TG dramatically increased the appearance of P-eIF2 after just 30 min of treatment. These results demonstrate that oxidative stress and calcium release are two ER stress-inducing factors that synergize when applied together and that calcium release is not likely to be the only process responsible for UPR activation during oxidative stress. Regarding GRP94 protein levels, TG caused GRP94 overexpression only after 24 h (Fig. 6A). Since various authors have proposed that ER stress is one of the oxidative pathways leading to cell death, we then decided to address the question of whether the potentiating effect of TG on the ER stress induced by Asc/Men was also accompanied by an increase in cell death. For this purpose, cell survival was measured in cells exposed for different durations to TG, Asc/Men $0.5 / 5$, or both. Fig. $6 B$ shows that incubation with Asc/Men $0.5 / 5$ or TG resulted in a slow reduction in MCF-7 cell survival, reaching levels of $52.6 \pm 7.3$ and $66.4 \pm 9.5$ after $24 \mathrm{~h}$, respectively. The combination of the two treatments resulted in enhancement of cell death, especially in the 6 th hour of treatment $(\mathrm{p}<0.01$ for TG + Asc/Men $0.5 / 5$ compared to TG 
alone and $\mathrm{p}<0.05$ compared to Asc/Men). This experiment supports a role of ER stress in processes of oxidative stress-induced cell death.

Previous studies have revealed that TG exposure is generally associated with DNA fragmentation [43-45]. Asc/Men treatment also triggers this event, which results in poly(ADP ribose) polymerase (PARP) activation and $\mathrm{NAD}^{+}$depletion (Fig. 3 and Verrax et al., 2004 and 2007 [31, 33]). We, therefore, assessed the effects of TG and Asc/Men treatment on histone H2AX phosphorylation, a marker of DNA damage in the form of double-strand breaks. As presented in Fig. $6 C, 4 \mathrm{~h}$ of treatment with TG and Asc/Men 0.5/5 induced the appearance of $\gamma-\mathrm{H} 2 \mathrm{AX}$ (the phosphorylated form) only when both treatments were applied together, demonstrating that increased calcium release and consecutive ER stress also potentiate oxidative stress-induced DNA fragmentation.

\section{Discussion}

The present study was designed to elucidate the roles of disturbances in calcium homeostasis and of ER stress in oxidative stress-associated death in MCF-7 cells. Our results reveal that Asc/Men-induced oxidative stress elicits $\left[\mathrm{Ca}^{2+}\right]_{\mathrm{er}}$ release, ER stress and increase in $\left[\mathrm{Ca}^{2+}\right]_{\mathrm{c}}$ after drug exposure. In this model, ER stress and associated $\left[\mathrm{Ca}^{2+}\right]_{\mathrm{er}}$ emptying, but not alterations in $\left[\mathrm{Ca}^{2+}\right]_{\mathrm{c}}$, appear to have a role in cell death induction.

The first finding of our study is that the pro-oxidant association of Asc/Men induces a slow increase in cytosolic calcium. Use of iodoacetate in order to mimic Asc/Men-induced depletion in ATP did not trigger cytoplasmic calcium overload, suggesting that ATP depletion was not the cause of the large increase in intracellular calcium observed during oxidative exposure. One goal of our study was to clarify the link between the identified oxidative 
increase in cytosolic calcium and MCF-7 cell death. Various data provide evidence that alterations in $\left[\mathrm{Ca}^{2+}\right]_{\mathrm{c}}$ are not involved in oxidative toxicity: First, using specific inhibitors of pathways that have already been proposed to participate in calcium-mediated oxidative toxicity [5], we could not demonstrate any role of enzymes, such as proteases, calmodulinassociated enzymes or calcium-dependent endonucleases, in these processes. The potential involvement of mitochondria was also tested. Indeed, it is known that exposure of mitochondria to high calcium concentrations during oxidative stress results in their swelling and uncoupling. This phenomenon leads to a loss of maintenance of cellular ATP levels and finally to cell death by necrosis [46]. In our study, use of Ru360, a specific mitochondrial calcium uptake inhibitors (uniport transporter inhibitor) and cyclosporine A (a mPTP inhibitor) was not associated with any effect on Asc/Men toxicity. This suggests that mitochondrial calcium uptake was not involved in the toxicity in our model and contrasts with reports examining the role of mitochondrial permeability transition in the cytotoxicity of the pro-oxidant, tert-butylhydroperoxide [47]. Secondly, depleting or chelating extracellular calcium (by EGTA) was not protective against loss of cell viability during oxidative stress. Because EGTA, in addition to its effect on extracellular calcium, tends to draw intracellular calcium (as shown in Figs. $5 A$ and $B$ ), its lack of effect on cell viability can be considered as another argument against the involvement of altered $\left[\mathrm{Ca}^{2+}\right]_{\mathrm{c}}$ in oxidative toxicity. Furthermore, we found that media without calcium and with $200 \mu \mathrm{M}$ EGTA, could not preserve cell viability during Asc/Men exposure (not shown). This observation is in agreement with the report of Persoon-Rothert and colleagues in 1994 [48]. Thirdly, BAPTAAM, one of the most used intracellular calcium chelator, was shown to protect cells from oxidative modifications during Asc/Men exposure (Fig. 3D). The protective effect of this chelator is generally the principal argument for a connection between $\left[\mathrm{Ca}^{2+}\right]_{\mathrm{c}}$ deregulation and oxidative injury. Our results suggest that BAPTA-AM may interact with pro-oxidative 
mechanisms in our model. However, it cannot be ruled out that BAPTA-AM could also chelate intracellular calcium, and protects cells in this way from oxidative toxicity. These are still speculations and need further study. It has been proposed that BAPTA-AM interferes with Fenton's reaction [41, 42] or may protect against a poorly defined pro-oxidative calciumassociated process, such as calcium-induced iron release [49] or ER stress-generated ROS production [50-52].

The typical profile of the intracellular calcium response identified in our study has also been observed in other cell lines exposed to $\mathrm{H}_{2} \mathrm{O}_{2}$, such as HeLa, human erythrocytes and MDCK (a canine epithelial cell line) [53], CRI-G1 (an insulin-secreting cell line) [54] or pancreatic acinar cells $[14,55]$. However, to our knowledge, this is the first time this effect has been demonstrated in MCF-7 cells. Although high concentrations of $\mathrm{H}_{2} \mathrm{O}_{2}$ have been shown to induce a similar calcium response to that seen in our study, there is no consensus regarding the source of calcium, as highlighted and discussed in the study by Castro et al., [53]. These authors reported that the increase in intracellular calcium increase came largely from a cytosolic unrecognized source. Although it was not the main goal of our study, we found that ER calcium release could partly explain the elevation in $\left[\mathrm{Ca}^{2+}\right]_{\mathrm{c}}$ in MCF-7 cells exposed to oxidative stress. This is in agreement with previous reports exploring the effects of $\mathrm{H}_{2} \mathrm{O}_{2}$ exposure on modulation of calcium homeostasis [13, 14].

Oxidative stress encompasses a number of ER stress inducing factors, including calcium emptying (presumably by inhibition of calcium ATPase $[15,16,56]$ ), or direct oxidative damage to newly folded proteins or proteins of the ER machinery. However, the relative contributions of these events in oxidative stress-induced ER stress are not known.

Furthermore, the relationship between oxidative stress and ER stress is a matter of debate, because activation of the UPR can also result in ROS generation [50-52]. In our study, we found that pro-oxidant Asc/Men treatment induced the translational control arm of the UPR 
(by enhancing eIF2 phosphorylation) and upregulation of ER folding capacity (by the increase in GRP94 protein, one of the major ER chaperones). These events were accompanied by a slow leakage of $\left[\mathrm{Ca}^{2+}\right]_{\mathrm{er}}$. Given these results, we then focused on the potential link between ER calcium release and ER stress activation. For this purpose, TG was used as an UPR inducer to trigger irreversible calcium release from the ER. We showed that TG and consequent calcium emptying also induced eIF2 phosphorylation shortly after addition of TG. This effect was weaker than that observed after exposure of cells to ascorbate or menadione at concentrations of $1 \mathrm{mM}$ and $10 \mu \mathrm{M}$, respectively (Fig. $5 D$ and $6 A$ ), suggesting that the $\left[\mathrm{Ca}^{2+}\right]_{\mathrm{er}}$ leak was not sufficient to explain the oxidative stress-induced UPR activation in our model. Moreover, the combination of oxidative stress and TG-induced ER $\left[\mathrm{Ca}^{2+}\right]_{\mathrm{er}}$ release resulted in a greater and more rapid eIF2 phosphorylation, in a synergistic manner. This clearly demonstrates that ER calcium depletion is not the main process responsible for ER stress induction by oxidative stress.

The involvement of ER stress and consequent UPR activation in the processes of oxidative stress-induced cell death has not been elucidated. Here, we showed that $\left[\mathrm{Ca}^{2+}\right]_{\mathrm{er}}$ release potentiates Asc/Men-associated ER stress and cytotoxicity. This suggests that ER stress is involved in the processes of oxidative stress-induced cell death. Moreover, this is in agreement with previous reports which showed that increasing ER folding capacity (by transfection with an ER chaperone) or decreasing UPR can markedly attenuate ROS-induced apoptosis in other cell lines [19, 24-26]. These findings also confirm results from the study by Hung et al., in which protection of ER calcium release by overexpression of the major ER $\mathrm{Ca}^{2+}$-binding protein, calreticulin, protected against $\mathrm{H}_{2} \mathrm{O}_{2}$-induced cell injury [26]. In addition, in our study, $\left[\mathrm{Ca}^{2+}\right]_{\mathrm{er}}$ emptying also potentiated Asc/Men-induced DNA fragmentation and associated histone $\mathrm{H} 2 \mathrm{AX}$ phosphorylation, suggesting that ER stress could 
represent one of the pathways leading to this event; this observation also underlines the capacity of TG to trigger DNA fragmentation, as shown by others [43-45, 57].

In conclusion, in this study we report the major role of disrupted ER calcium homeostasis on Asc/Men oxidative toxicity in MCF-7 cells and highlight the relative contribution of ER stress in this process. Our results confirm the pro-oxidant activity of the association of ascorbate and menadione $[29-33,35,58,59]$ and suggest that it could represent an interesting therapy in tumors in which increased ER folding capacity is associated with cancer resistance.

\section{Acknowledgements}

The authors would like to thank Isabelle Blave and Véronique Allaeys for their excellent technical assistance. This work was supported by grants from Televie and the Belgian Fonds National de la Recherche Scientifique (7.4566.07) and and by grant ARC 05/10-328 from the General Direction of Scientific Research of the French Community of Belgium. Raphaël Beck is a FRIA recipient. Julien Verrax and Nicolas Tajeddine are FNRS Post-Doctoral Researchers, and Nicolas Dejeans is a Televie-FNRS Post-Doctoral Researcher. We dedicate this work to the late Dr. Henryk Taper, in honor of his pioneering studies on the association of ascorbate and menadione. 


\section{References}

[1] Orrenius S, Zhivotovsky B, Nicotera P. Regulation of cell death: the calciumapoptosis link. Nat Rev Mol Cell Biol 2003;4:552-65.

[2] Nicotera P, Orrenius S. Ca2+ and cell death. Ann N Y Acad Sci 1992;648:17-27.

[3] Berridge MJ, Bootman MD, Lipp P. Calcium--a life and death signal. Nature 1998;395:645-8

[4] Trump BF, Berezesky IK. Calcium-mediated cell injury and cell death. FASEB J 1995;9:219-28.

[5] Ermak G, Davies KJ. Calcium and oxidative stress: from cell signaling to cell death. Mol Immunol 2002;38:713-21.

[6] Zhang K, Kaufman RJ. Protein folding in the endoplasmic reticulum and the unfolded protein response. Handb Exp Pharmacol 2006:69-91.

[7] Schroder M, Kaufman RJ. The mammalian unfolded protein response. Annu Rev Biochem 2005;74:739-89.

[8] Ni M, Lee AS. ER chaperones in mammalian development and human diseases. FEBS Lett 2007;581:3641-51.

[9] Dong D, Ko B, Baumeister P, Swenson S, Costa F, Markland F, et al. Vascular targeting and antiangiogenesis agents induce drug resistance effector GRP78 within the tumor microenvironment. Cancer Res 2005;65:5785-91.

[10] Pyrko P, Schonthal AH, Hofman FM, Chen TC, Lee AS. The unfolded protein response regulator GRP78/BiP as a novel target for increasing chemosensitivity in malignant gliomas. Cancer Res 2007;67:9809-16. 
[11] Malhotra JD, Kaufman RJ. Endoplasmic reticulum stress and oxidative stress: a vicious cycle or a double-edged sword? Antioxid Redox Signal 2007;9:2277-93.

[12] Tagliarino C, Pink JJ, Dubyak GR, Nieminen AL, Boothman DA. Calcium is a key signaling molecule in beta-lapachone-mediated cell death. J Biol Chem 2001;276:19150-9.

[13] Doan TN, Gentry DL, Taylor AA, Elliott SJ. Hydrogen peroxide activates agonistsensitive $\mathrm{Ca}(2+)$-flux pathways in canine venous endothelial cells. Biochem $\mathrm{J}$ 1994;297 ( Pt 1):209-15.

[14] Bruce JI, Elliott AC. Oxidant-impaired intracellular Ca2+ signaling in pancreatic acinar cells: role of the plasma membrane Ca2+-ATPase. Am J Physiol Cell Physiol 2007;293:C938-50.

[15] Kaplan P, Babusikova E, Lehotsky J, Dobrota D. Free radical-induced protein modification and inhibition of Ca2+-ATPase of cardiac sarcoplasmic reticulum. Mol Cell Biochem 2003;248:41-7.

[16] Moreau VH, Castilho RF, Ferreira ST, Carvalho-Alves PC. Oxidative damage to sarcoplasmic reticulum Ca2+-ATPase AT submicromolar iron concentrations: evidence for metal-catalyzed oxidation. Free Radic Biol Med 1998;25:554-60.

[17] van der Vlies D, Makkinje M, Jansens A, Braakman I, Verkleij AJ, Wirtz KW, et al. Oxidation of ER resident proteins upon oxidative stress: effects of altering cellular redox/antioxidant status and implications for protein maturation. Antioxid Redox Signal 2003;5:381-7.

[18] Merksamer PI, Trusina A, Papa FR. Real-time redox measurements during endoplasmic reticulum stress reveal interlinked protein folding functions. Cell 2008;135:933-47. 
[19] Yokouchi M, Hiramatsu N, Hayakawa K, Okamura M, Du S, Kasai A, et al. Involvement of selective reactive oxygen species upstream of proapoptotic branches of unfolded protein response. J Biol Chem 2008;283:4252-60.

[20] Min SK, Lee SK, Park JS, Lee J, Paeng JY, Lee SI, et al. Endoplasmic reticulum stress is involved in hydrogen peroxide induced apoptosis in immortalized and malignant human oral keratinocytes. J Oral Pathol Med 2008;37:490-8.

[21] Harding HP, Zhang Y, Zeng H, Novoa I, Lu PD, Calfon M, et al. An integrated stress response regulates amino acid metabolism and resistance to oxidative stress. Mol Cell 2003;11:619-33.

[22] Baker KM, Chakravarthi S, Langton KP, Sheppard AM, Lu H, Bulleid NJ. Low reduction potential of Erolalpha regulatory disulphides ensures tight control of substrate oxidation. EMBO J 2008;27:2988-97.

[23] Gorlach A, Klappa P, Kietzmann T. The endoplasmic reticulum: folding, calcium homeostasis, signaling, and redox control. Antioxid Redox Signal 2006;8:1391-418.

[24] Yokouchi M, Hiramatsu N, Hayakawa K, Kasai A, Takano Y, Yao J, et al. Atypical, bidirectional regulation of cadmium-induced apoptosis via distinct signaling of unfolded protein response. Cell Death Differ 2007;14:1467-74.

[25] Sanson M, Auge N, Vindis C, Muller C, Bando Y, Thiers JC, et al. Oxidized lowdensity lipoproteins trigger endoplasmic reticulum stress in vascular cells: prevention by oxygen-regulated protein 150 expression. Circ Res 2009;104:328-36.

[26] Hung CC, Ichimura T, Stevens JL, Bonventre JV. Protection of renal epithelial cells against oxidative injury by endoplasmic reticulum stress preconditioning is mediated by ERK1/2 activation. J Biol Chem 2003;278:29317-26.

[27] Kadara H, Lacroix L, Lotan D, Lotan R. Induction of endoplasmic reticulum stress by the pro-apoptotic retinoid $\mathrm{N}$-(4-hydroxyphenyl)retinamide via a reactive oxygen 
species-dependent mechanism in human head and neck cancer cells. Cancer Biol Ther 2007;6:705-11.

[28] Wu HL, Li YH, Lin YH, Wang R, Li YB, Tie L, et al. Salvianolic acid B protects human endothelial cells from oxidative stress damage: a possible protective role of glucose-regulated protein 78 induction. Cardiovasc Res 2009;81:148-58.

[29] Calderon PB, Cadrobbi J, Marques C, Hong-Ngoc N, Jamison JM, Gilloteaux J, et al. Potential therapeutic application of the association of vitamins $\mathrm{C}$ and $\mathrm{K} 3$ in cancer treatment. Curr Med Chem 2002;9:2271-85.

[30] Taper HS, de Gerlache J, Lans M, Roberfroid M. Non-toxic potentiation of cancer chemotherapy by combined C and K3 vitamin pre-treatment. Int J Cancer $1987 ; 40: 575-9$.

[31] Verrax J, Vanbever S, Stockis J, Taper H, Calderon PB. Role of glycolysis inhibition and poly(ADP-ribose) polymerase activation in necrotic-like cell death caused by ascorbate/menadione-induced oxidative stress in K562 human chronic myelogenous leukemic cells. Int J Cancer 2007;120:1192-7.

[32] Verrax J, Stockis J, Tison A, Taper HS, Calderon PB. Oxidative stress by ascorbate/menadione association kills K562 human chronic myelogenous leukaemia cells and inhibits its tumour growth in nude mice. Biochem Pharmacol 2006;72:67180.

[33] Verrax J, Cadrobbi J, Marques C, Taper H, Habraken Y, Piette J, et al. Ascorbate potentiates the cytotoxicity of menadione leading to an oxidative stress that kills cancer cells by a non-apoptotic caspase-3 independent form of cell death. Apoptosis 2004;9:223-33.

[34] Verrax J, Calderon PB. The controversial place of vitamin C in cancer treatment. Biochem Pharmacol 2008;76:1644-52. 
[35] Verrax J, Delvaux M, Beghein N, Taper H, Gallez B, Buc Calderon P. Enhancement of quinone redox cycling by ascorbate induces a caspase-3 independent cell death in human leukaemia cells. An in vitro comparative study. Free Radic Res 2005;39:64957.

[36] Beck R, Verrax J, Dejeans N, Taper H, Calderon PB. Menadione Reduction by Pharmacological Doses of Ascorbate Induces an Oxidative Stress That Kills Breast Cancer Cells. Int J Toxicol 2009;28:33-42.

[37] Mosmann T. Rapid colorimetric assay for cellular growth and survival: application to proliferation and cytotoxicity assays. J Immunol Methods 1983;65:55-63.

[38] Pigozzi D, Ducret T, Tajeddine N, Gala JL, Tombal B, Gailly P. Calcium store contents control the expression of TRPC1, TRPC3 and TRPV6 proteins in LNCaP prostate cancer cell line. Cell Calcium 2006;39:401-15.

[39] Palmer AE, Jin C, Reed JC, Tsien RY. Bcl-2-mediated alterations in endoplasmic reticulum $\mathrm{Ca} 2+$ analyzed with an improved genetically encoded fluorescent sensor. Proc Natl Acad Sci U S A 2004;101:17404-9.

[40] Robinson JA, Jenkins NS, Holman NA, Roberts-Thomson SJ, Monteith GR. Ratiometric and nonratiometric $\mathrm{Ca} 2+$ indicators for the assessment of intracellular free $\mathrm{Ca} 2+$ in a breast cancer cell line using a fluorescence microplate reader. J Biochem Biophys Methods 2004;58:227-37.

[41] Britigan BE, Rasmussen GT, Cox CD. Binding of iron and inhibition of irondependent oxidative cell injury by the "calcium chelator" 1,2-bis(2aminophenoxy)ethane N,N,N',N'-tetraacetic acid (BAPTA). Biochem Pharmacol $1998 ; 55: 287-95$. 
[42] Glickstein H, El RB, Shvartsman M, Cabantchik ZI. Intracellular labile iron pools as direct targets of iron chelators: a fluorescence study of chelator action in living cells. Blood 2005;106:3242-50.

[43] Nakano T, Watanabe H, Ozeki M, Asai M, Katoh H, Satoh H, et al. Endoplasmic reticulum $\mathrm{Ca} 2+$ depletion induces endothelial cell apoptosis independently of caspase12. Cardiovasc Res 2006;69:908-15.

[44] Wei H, Wei W, Bredesen DE, Perry DC. Bcl-2 protects against apoptosis in neuronal cell line caused by thapsigargin-induced depletion of intracellular calcium stores. J Neurochem 1998;70:2305-14.

[45] Nguyen HN, Wang C, Perry DC. Depletion of intracellular calcium stores is toxic to SH-SY5Y neuronal cells. Brain Res 2002;924:159-66.

[46] Halestrap AP. Calcium, mitochondria and reperfusion injury: a pore way to die. Biochem Soc Trans 2006;34:232-7.

[47] Lemasters JJ, Theruvath TP, Zhong Z, Nieminen AL. Mitochondrial calcium and the permeability transition in cell death. Biochim Biophys Acta 2009.

[48] Persoon-Rothert M, Egas-Kenniphaas JM, van der Valk-Kokshoorn EJ, Buys JP, van der Laarse A. Oxidative stress-induced perturbations of calcium homeostasis and cell death in cultured myocytes: role of extracellular calcium. Mol Cell Biochem $1994 ; 136: 1-9$.

[49] Kim HJ, Kim SG. Alterations in cellular $\mathrm{Ca}(2+)$ and free iron pool by sulfur amino acid deprivation: the role of ferritin light chain down-regulation in prooxidant production. Biochem Pharmacol 2002;63:647-57.

[50] Haynes CM, Titus EA, Cooper AA. Degradation of misfolded proteins prevents ERderived oxidative stress and cell death. Mol Cell 2004;15:767-76. 
[51] Malhotra JD, Miao H, Zhang K, Wolfson A, Pennathur S, Pipe SW, et al. Antioxidants reduce endoplasmic reticulum stress and improve protein secretion. Proc Natl Acad Sci U S A 2008;105:18525-30.

[52] Santos CX, Tanaka LY, Wosniak JJ, Laurindo FR. Mechanisms and Implications of Reactive Oxygen Species Generation During the Unfolded Protein Response: Roles of Endoplasmic Reticulum Oxidoreductases, Mitochondrial Electron Transport and NADPH Oxidase. Antioxid Redox Signal 2009.

[53] Castro J, Bittner CX, Humeres A, Montecinos VP, Vera JC, Barros LF. A cytosolic source of calcium unveiled by hydrogen peroxide with relevance for epithelial cell death. Cell Death Differ 2004;11:468-78.

[54] Herson PS, Lee K, Pinnock RD, Hughes J, Ashford ML. Hydrogen peroxide induces intracellular calcium overload by activation of a non-selective cation channel in an insulin-secreting cell line. J Biol Chem 1999;274:833-41.

[55] Baggaley EM, Elliott AC, Bruce JI. Oxidant-induced inhibition of the plasma membrane Ca2+-ATPase in pancreatic acinar cells: role of the mitochondria. Am J Physiol Cell Physiol 2008;295:C1247-60.

[56] Castilho RF, Carvalho-Alves PC, Vercesi AE, Ferreira ST. Oxidative damage to sarcoplasmic reticulum $\mathrm{Ca}(2+)$-pump induced by $\mathrm{Fe} 2+/ \mathrm{H} 2 \mathrm{O} 2 /$ ascorbate is not mediated by lipid peroxidation or thiol oxidation and leads to protein fragmentation. Mol Cell Biochem 1996;159:105-14.

[57] Pigozzi D, Tombal B, Ducret T, Vacher P, Gailly P. Role of store-dependent influx of $\mathrm{Ca} 2+$ and efflux of $\mathrm{K}+$ in apoptosis of CHO cells. Cell Calcium 2004;36:421-30.

[58] Taper HS, Keyeux A, Roberfroid M. Potentiation of radiotherapy by nontoxic pretreatment with combined vitamins $\mathrm{C}$ and $\mathrm{K} 3$ in mice bearing solid transplantable tumor. Anticancer Res 1996;16:499-503. 
[59] Verrax J, Pedrosa RC, Beck R, Dejeans N, Taper H, Calderon PB. In situ modulation of oxidative stress: a novel and efficient strategy to kill cancer cells. Curr Med Chem 2009;16:1821-30.

\section{FIGURE LEGENDS}

Fig. 1 - Asc/Men exposure triggers increase in intracellular calcium. A, intracellular calcium levels were measured in living cells using the calcium indicator dye, fluo-3/AM. Cells were preincubated for $30 \mathrm{~min}$ at $37^{\circ} \mathrm{C}$ and for a further 30 minutes at room temperature with $25 \mu \mathrm{M}$ fluo-3/AM. Cells were then incubated at $37^{\circ} \mathrm{C}$ for different time periods in the presence of Asc/Men or in medium alone. For times 0 and $90 \mathrm{mn}$, cells were incubated for 90 $\mathrm{mn}$ in medium alone or in medium with Asc/Men. For times 30 and $60 \mathrm{mn}$, cells were incubated first with medium alone for 60 or $30 \mathrm{mn}$ respectively before Asc/Men (to achieve the final incubation time of $90 \mathrm{mn}$ between Fluo-3/AM loading and fluorescent measurement). Intracellular calcium levels were quantified using a fluorescence microplate reader as described under Section 2. Results are expressed as $\Delta \mathrm{F} / \mathrm{F} 0 . \boldsymbol{B}$, intracellular calcium concentration was measured in living cells exposed or not to Asc/Men for 90 min (80 cells for each group of 4 experiments), using the calcium indicator dye, fura-2, AM as described under Section 2. Results represent means \pm SEM. $C$, cells were cultured in the presence of Asc/Men for different time periods (number of minutes indicated above). One hour before the end of the study, fluo-3/AM was added to the final concentration of $25 \mu \mathrm{M}$. At the end of the incubation, cells were washed and incubated in HBSS with propidium iodide (PI) just before acquisition of images of calcium and PI penetration.

Fig. 2 - Influence of different inhibitors of calcium-associated death pathways or the antioxidant NAC, on Asc/Men-induced loss of cell viability. Cell viability was measured by MTT tests as described under Section 2. $\boldsymbol{A}$ and $\boldsymbol{B}$, cells were preincubated with different 
inhibitors of: calmodulins (W-7, 25 $\mu \mathrm{M}, 1 \mathrm{~h}$ ), calpains (calpeptin [Calp], $10 \mu \mathrm{M}, 1 \mathrm{~h}$ ), calcium-dependent endonucleases (aurintricarboxylic acid [ATA], $100 \mu \mathrm{M}, 1 \mathrm{~h}$ ), mitochondrial calcium uptake $(\mathrm{Ru} 360[\mathrm{Ru}], 5 \mu \mathrm{M}, 1 \mathrm{~h})$ or with a mitochondrial permeability transition pore (mPTP) inhibitor (cyclosporine-A [CsA], $5 \mu \mathrm{M}, 2 \mathrm{~h}$ ). When indicated, cells were pre-incubated with $\mathrm{N}$-acetyl cysteine (NAC, $3 \mathrm{mM}$ ) $15 \mathrm{~min}$ before Asc/Men. Cells were then incubated for $24 \mathrm{~h}(\boldsymbol{A})$ or $4 \mathrm{~h}(\boldsymbol{B})$ in the presence of $1 \mathrm{mM}$ ascorbate, $10 \mu \mathrm{M}$ of menadione (Asc/Men), and the different inhibitors. All results are shown as means \pm SD $(\mathrm{n}=2) . \boldsymbol{C}$, in order to obtain calcium-free conditions, media without calcium and without serum were used. Because serum depletion could itself influence the MTT test results, two experimental control conditions were added in which cells in serum-free medium were exposed or not to Asc/Men. Cells were incubated with or without Asc/Men for $4 \mathrm{~h}$, in the presence or absence of calcium, fetal bovine serum (FBS), or 2 mM EGTA, then the MTT test was performed. Results are expressed as percentages of control and represent means \pm SD $(\mathrm{n}=3) . * * *$ statistically different $(\mathrm{p}<0.001)$ from the corresponding condition without Asc/Men.

Fig. 3 - Effect of BAPTA-AM in the process of Asc/Men induced cell death. A, cells were preincubated with different concentrations of BAPTA-AM for 15 min (BA), washed and incubated for $24 \mathrm{~h}$ in the presence of $1 \mathrm{mM}$ ascorbate and $10 \mu \mathrm{M}$ of menadione (Asc/Men). Cell viability was then assessed as described in the experimental procedure section. $\boldsymbol{B}$, BAPTA-AM and NAC inhibit the Asc/Men-induced decrease in ATP. Cells were preincubated with $10 \mu \mathrm{M}$ BAPTA-AM (BA) or $3 \mathrm{mM}$ of the antioxidant, NAC, for $15 \mathrm{~min}$, washed and incubated for the time indicated in the presence of $1 \mathrm{mM}$ ascorbate and $10 \mu \mathrm{M}$ of menadione (Asc/Men). The graph represents the ATP content of the cells, expressed as nmol $/ 10^{6}$ cells. $\boldsymbol{C}-\boldsymbol{D}$, cells were preincubated or not with 5 or $10 \mu \mathrm{M}$ BAPTA-AM or $3 \mathrm{mM}$ NAC for $15 \mathrm{~min}$. Cells were then washed and exposed to $1 \mathrm{mM}$ ascorbate and/or $10 \mu \mathrm{M}$ of 
menadione (Asc/Men) for the indicated times at $37^{\circ} \mathrm{C}$. Cells were then washed twice with PBS and lysed. DNA cleavage and activation of poly (ADP-ribose) polymerase (PARP) were evaluated by immunoblotting with antibodies that specifically recognize the phosphorylated form of histone $\mathrm{H} 2 \mathrm{AX}(\gamma-\mathrm{H} 2 \mathrm{AX})$ or poly-ADP-ribosylated proteins $(\boldsymbol{C})$. The presence of PeIF2 or levels of protein carbonylation were measured by western blot as described in the experimental procedures section $(\boldsymbol{D})$. Blots are representative examples of one of 3 independent experiments. For graphs, results are expressed as percentages of control and represent means $\pm \operatorname{SD}(\mathrm{n}=3)$. *** statistically different $(\mathrm{p}<0.001)$ from the corresponding condition without Asc/Men. Groups a, b and c were statistically different (at least $\mathrm{p}<0.05$ ).

Fig. 4 - Decrease in ATP was not associated with increase in intracellular calcium. $A$-B, cells were incubated for the indicated time in the presence of $1 \mathrm{mM}$ ascorbate and $10 \mu \mathrm{M}$ of menadione (Asc/Men) or with the glycolysis inhibitor, iodoacetate (Iodo), at a concentration of $100 \mu \mathrm{M}$. The ATP content of cells was then measured. The graphs represent the ATP content of the cells expressed as nmol $/ 10^{6}$ cells. $\boldsymbol{C}$, intracellular calcium levels were measured in live cells using the calcium indicator dye, fluo-3/AM, as described under Section 2. Cells were preincubated for 30 minutes at $37^{\circ} \mathrm{C}$ and then for a further 30 minutes at room temperature with $25 \mu \mathrm{M}$ fluo-3/AM. Cells were then incubated in the presence of $1 \mathrm{mM}$ ascorbate and $10 \mu \mathrm{M}$ of menadione (Asc/Men) or $100 \mu \mathrm{M}$ iodoacetate for $90 \mathrm{~min}$ at $37^{\circ} \mathrm{C}$. All results are shown as means \pm SD of 3 separate experiments and groups $a, b$ and c were statistically different (at least $\mathrm{p}<0.05$ ).

Fig. 5 - Asc/Men exposure partially releases ER calcium and induces ER stress. A, B and $\boldsymbol{C}$, cytosolic calcium was assessed using the ratiometric dye, fura-2. The release of $\left[\mathrm{Ca}^{2+}\right]_{\mathrm{er}}$ by thapsigargin (TG) was compared in 80 Asc/Men-treated cells (from 4 experiments) versus 80 control (from 4 experiments) MCF-7 cells. Typical profile responses of a control cell and a cell pre-treated for $90 \mathrm{~min}$ with Asc/Men are presented in $\boldsymbol{A}$ and $\boldsymbol{B}$, respectively. Extracellular 
calcium was depleted 5 min before addition of TG $(1 \mu \mathrm{M})$ in order to avoid capacitative calcium influx. TG mediated $\left[\mathrm{Ca}^{2+}\right]_{\mathrm{c}}$ increase $\left(\Delta\left[\mathrm{Ca}^{2+}\right]\right)$ was quantified by the difference between maximal $\left[\mathrm{Ca}^{2+}\right]_{\mathrm{c}}$ after and minimal $\left[\mathrm{Ca}^{2+}\right]_{\mathrm{c}}$ before TG treatment for the 160 cells and is shown in $\boldsymbol{C}$. Results represent means \pm SEM. $\boldsymbol{D}$, cells were incubated in the presence of ascorbate $(1 \mathrm{mM})$ and menadione $(10 \mu \mathrm{M})($ Asc/Men 1/10). At the indicated times, cells were washed twice with PBS and lysed. The relative abundances of P-eIF2 and GRP94 were measured by western blot as described under Section 2. Actin was used as a loading control for each lane. Blots are representative examples of one of 3 independent experiments.

Fig. 6 - ER calcium release potentiates ER stress and cell death caused by Asc/Men. $A$ and $\boldsymbol{B}$, cells were incubated in the presence of ascorbate $(0.5 \mathrm{mM})$ and menadione $(5 \mu \mathrm{M})$ (Asc/Men 0.5/5), $1 \mu \mathrm{M}$ thapsigargin (TG) or both for indicated times. After treatment, cells were washed twice with PBS and lysed. The presence of P-eIF2 and GRP94 (A) or $\gamma$-H2AX $(\boldsymbol{C})$ was measured by western blot as described under Section 2. Actin was used as a loading control for each lane. Blots are representative examples of one of 3 independent experiments. $\boldsymbol{B}$, the effects of Asc/Men and TG on cell survival was monitored by the erythrosine exclusion assay, as described under Section 2. Cells were incubated for different time periods in the absence or presence of the different compounds and non-erythrosine positive cells were counted. All experiments represent means \pm SD of 4 separate experiments. Significant as compared to control, $\left(^{*}\right) \mathrm{p}<0.05,(* *) \mathrm{p}<0.01,(* * *) \mathrm{p}<0.001$; significant as compared to TG, (\#) $\mathrm{p}<0.05$, (\#\#) $\mathrm{p}<0.01$; significant as compared to Asc/Men $0.5 / 5,(\dagger) \mathrm{p}<0.05)$. 


\title{
Endoplasmic reticulum calcium release potentiates the ER stress
}

\section{and cell death caused by an oxidative stress in MCF-7 cells}

\author{
Nicolas Dejeans ${ }^{\text {a }}$, Nicolas Tajeddine ${ }^{\text {b }}$, Raphaël Beck ${ }^{\text {a }}$, Julien Verrax ${ }^{\text {a }}$, Henryk Taper \\ ${ }^{a \dagger}$, Philippe Gailly ${ }^{\text {b }}$, Pedro Buc Calderon ${ }^{\text {a,c,** }}$. \\ ${ }^{a}$ Université Catholique de Louvain, Louvain Drug Research Institute, Toxicology and Cancer \\ Biology Research Group, PMNT Unit, Belgium \\ ${ }^{b}$ Université Catholique de Louvain, Laboratory of Cell Physiology, Belgium. \\ ${ }^{c}$ Departamento de Ciencias Quimicas y Farmaceuticas, Universidad Arturo Prat, Iquique,
}

Chile.

${ }^{\dagger}$ Died the 4th of April, 2009.

Running title: calcium and oxidative stress in cancer cell death

* Corresponding author. Pedro Buc Calderon, avenue E. Mounier 73, 1200 Bruxelles,

Belgium, Phone: +32 276473 66, Fax: +32 27647359

E-mail: pedro.buccalderon@uclouvain.be 


\section{ABSTRACT}

Increase in cytosolic calcium concentration $\left(\left[\mathrm{Ca}^{2+}\right]_{\mathrm{c}}\right)$, release of endoplasmic reticulum (ER) calcium $\left(\left[\mathrm{Ca}^{2+}\right]_{\mathrm{er}}\right)$ and ER stress have been proposed to be involved in oxidative toxicity. Nevertheless, their relative involvements in the processes leading to cell death are not well defined. In this study, we investigated whether oxidative stress generated during ascorbatedriven menadione redox cycling (Asc/Men) could trigger these three events, and, if so, whether they contributed to Asc/Men cytoxicity in MCF-7 cells. Using microspectrofluorimetry, we demonstrated that Asc/Men-generated oxidative stress was associated with a slow and moderate increase in $\left[\mathrm{Ca}^{2+}\right]_{\mathrm{c}}$, largely preceding permeation of propidium iodide, and thus cell death. Asc/Men treatment was shown to partially deplete ER calcium stores after $90 \mathrm{~min}$ (decrease by $45 \%$ compared to control). This event was associated with ER stress activation, as shown by analysis of eIF2 phosphorylation and expression of the molecular chaperone GRP94. Thapsigargin (TG) was then used to study the effect of complete $\left[\mathrm{Ca}^{2+}\right]_{\text {er }}$ emptying during the oxidative stress generated by Asc/Men. Surprisingly, the combination of TG and Asc/Men increased ER stress to a level considerably higher than that observed for either treatment alone, suggesting that $\left[\mathrm{Ca}^{2+}\right]_{\text {er }}$ release alone is not sufficient to explain ER stress activation during oxidative stress. Finally, TG-mediated $\left[\mathrm{Ca}^{2+}\right]_{\mathrm{er}}$ release largely potentiated ER stress, DNA fragmentation and cell death caused by Asc/Men, supporting a role of ER stress in the process of Asc/Men cytotoxicity. Taken together, our results highlight the involvement of ER stress and $\left[\mathrm{Ca}^{2+}\right]_{\mathrm{er}}$ decrease in the process of oxidative stress-induced cell death in MCF-7 cells.

KEYWORDS: Oxidative stress, Breast cancer, Calcium homeostasis, Endoplasmic reticulum stress, MCF-7 cells, Ascorbate-driven menadione redox cycling. 


\section{Introduction}

It has long been known that disruption of intracellular calcium homeostasis is one of the primary processes in the early development of cell injury [1-3] and that elevation of intracellular calcium levels can provoke a switch from normal regulation of cell function to a signal for cell death [3]. Different mechanisms have been implicated in this phenomenon, including activation of calcium-dependent proteases (i.e., calpains), calmodulin-associated enzymes (i.e., the phosphatase and regulator calcineurin), and calcium-dependent endonucleases or apoptotic pathways associated with perturbations in mitochondrial calcium concentrations [3-5]. In oxidative stress, intracellular calcium deregulation has been shown to have a central role in the induction of apoptosis or necrosis [5].

Endoplasmic reticulum (ER) stress is an essential adaptive cell response to the accumulation of misfolded proteins and is induced by the quality control system that ensures the transit of correctly folded proteins to the Golgi [6]. The primary role of ER stress is to favor cell survival by increasing the capacity to fold or refold proteins or by facilitating the export of misfolded proteins to the cytosol and their subsequent degradation (ER-associated degradation or ERAD) [6]. This phenomenon requires a complex regulatory process, known as the unfolded protein response (UPR), which regulates the transcription and translation of a great number of genes [7]. This process can finally induce cell death, probably when the initial survival response cannot counteract the protein modifications [6]. The molecular processes of ER stress-induced cell death represent a promising research area as this event may be involved in the physiopathology of atherosclerosis, diabetes and cancer, diseases known to be closely linked to oxidative stress [8]. In tumors, UPR is activated in response to the microenvironment, generally hypoxic and low in energy. Thus, some ER chaperones 
appear to be potential biomarkers for tumor behavior and resistance to cancer therapies [8-10] and some researchers have proposed that ER stress proteins should be targeted to potentiate cancer treatments $[9,10]$.

Cells exposed to oxidative injury have various ER stress inducing factors [11]. Indeed, previous reports showed that oxidants can release ER calcium $\left(\left[\mathrm{Ca}^{2+}\right]_{\mathrm{er}}\right)[5,12-14]$ (presumably by inhibition of sarcoplasmic calcium ATPase $[15,16]$ ); this could represent a first mechanism by which oxidative injury can cause ER stress. Another possibility is that reactive oxygen species (ROS) may cause ER stress through generation and accumulation of oxidized proteins $[11,17]$. The ER appears to be particularly sensitive to such modifications [18-21], as its molecular environment has a high oxidizing redox potential, specialized in protein folding and disulfide bond formation [18, 22, 23]. Finally, ROS could directly damage proteins of the ER folding machinery, such as ER chaperones, and induce an accumulation of misfolded proteins and consequent UPR activation. Despite these data, research on the involvement of ER stress in the cellular response to ROS exposure is only emerging [11]. Few authors have reported UPR activation during oxidative stress and even fewer have demonstrated a direct involvement of ER stress in oxidative toxicity [19, 24-28]. In summary, ER homeostasis is a fragile equilibrium, which can be modulated by dysregulation of calcium or oxidative/reductive balance, features previously associated with oxidative stress. However, studies of the links between these factors are scarce.

We and others have shown that the association of ascorbate and menadione is an $\mathrm{H}_{2} \mathrm{O}_{2-}$ generating system that results in necrosis-like cell death in a wide variety of cancer cell types [29-35] including MCF-7 cells (a human breast derived cell line), and that loss of calcium homeostasis appeared to be a major factor in the cytotoxicity [36]. The aim of the present study was to investigate the role of disruption of calcium homeostasis and a potential involvement of ER stress in the mechanisms leading to cancer cell death from an oxidative 
stress. Using MCF-7 cells, we showed that 1) oxidative stress caused a slow increase in $\left[\mathrm{Ca}^{2+}\right]_{\mathrm{c}}$ concentration in MCF-7 cells; 2) this increase in $\left[\mathrm{Ca}^{2+}\right]_{\mathrm{c}}$ appeared not to be associated with oxidative stress cytotoxic pathways; 3 ) oxidative stress led to a partial release of $\left[\mathrm{Ca}^{2+}\right]_{\mathrm{er}}$; 4) calcium release was not the main causative factor in ER stress triggered by oxidative conditions; and 5) $\left[\mathrm{Ca}^{2+}\right]_{\mathrm{er}}$ release potentiated oxidative stress induced cell death.

\section{Materials and methods}

\subsection{Chemicals}

Menadione sodium bisulfite (Men), sodium ascorbate (Asc), N-acetylcysteine (NAC), BAPTA-AM, dimethylsulfoxide (DMSO), EGTA, ionomycin and W-7 hydrochloride were purchased from Sigma-Aldrich (St. Louis, MO). Thapsigargin (TG), aurintricarboxylic acid (ATA) and cyclosporine A (CsA) were purchased from Santa Cruz Biotechnology (Santa Cruz, CA), Calpeptin (Calp) and Ru360 from Calbiochem (San Diego, CA), fluo-3/AM from Tebu-Bio (Boechout, BE), fura-2, AM from Molecular Probes (Eugene, OR), Iodoacetate from Acros Organics (Geel, BE) and propidium iodide from Roche Diagnostics Corp (Indianapolis, IN). All other chemicals were ACS reagent grade.

\subsection{Cell Culture and Treatments}

The MCF-7 cell line was a gift from Dr. F. Brasseur (Ludwig Institute for Cancer Research, LICR-Brussels). The cells were cultured in DMEM (Dulbecco's modified eagle medium, (Gibco BRL, Life Technologies, Merelbeke, BE)) supplemented with 10\% fetal calf serum, penicillin $(10000 \mathrm{U} / \mathrm{ml})$, streptomycin $(10 \mathrm{mg} / \mathrm{ml})$ and $1.2 \%$ glutamine. The cultures were maintained at a density of about $50 \times 10^{3}$ cells $/ \mathrm{cm}^{2}$. The medium was changed at $48-72 \mathrm{~h}$ intervals. All cultures were maintained at $37^{\circ} \mathrm{C}$ in $95 \%$ air $/ 5 \% \mathrm{CO} 2$ with $100 \%$ humidity. For each passage, cells were washed twice with PBS (Gibco) and then incubated at $37^{\circ} \mathrm{C}$ with $0.25 \%$ trypsin-EDTA (Sigma-Aldrich, St Louis, MO). Cultures were treated with 1 or $0.5 \mathrm{mM}$ 
sodium ascorbate and 10 or $5 \mu \mathrm{M}$ menadione bisulfite as the $\mathrm{H}_{2} \mathrm{O}_{2}$-generating system. When indicated, the antioxidant NAC was added to cell cultures at a concentration of $3 \mathrm{mM}$ for 15 minutes before the addition of ascorbate and menadione. Cells were incubated with TG or iodoacetate at concentrations of 1 and $100 \mu \mathrm{M}$, respectively, to induce ER calcium release or glycolysis arrest, respectively.

\subsection{Cell survival measurement}

The effects of Asc/Men and TG on MCF-7 cell survival were monitored by the erythrosine exclusion assay. Cells were seeded onto 6-well plates at a density of 300000 cells/well for 24 $\mathrm{h}$ and then incubated for different durations in the absence or presence of the various compounds. Cells were then gently washed with $1 \mathrm{ml}$ PBS, harvested using trypsin-EDTA solution, collected and mixed with $100 \mu \mathrm{l}$ of medium. Then, $900 \mu \mathrm{l}$ of a solution containing $0.9 \% \mathrm{NaCl}$ and $0.4 \%$ erythosin $(\mathrm{w} / \mathrm{v})$ was added, the solution was gently mixed and nonerythrosine positive cells were immediately counted microscopically using a Burker chamber.

\subsection{MTT assay}

The effects of Asc/Men, TG or iodoacetate on cell metabolic status were assessed by following the reduction of MTT (3-(4,5-dimethylthiazolyl-2)-2,5-diphenyltetrazolium bromide) to blue formazan [37]. Briefly, cells were seeded into 96-well plates at a density of 10000 cells/well for $24 \mathrm{~h}$ and then incubated for different durations in the absence or in the presence of the various compounds ( 8 wells were used for each condition). Cells were then washed with PBS and incubated with MTT $(0.5 \mathrm{mg} / \mathrm{ml})$ for $2 \mathrm{~h}$ at $37^{\circ} \mathrm{C}$. Blue formazan crystals were solubilized by adding $100 \mu \mathrm{DMSO} /$ well, and the colored solution was subsequently read at $550 \mathrm{~nm}$. Results are expressed as \% of MTT reduction compared to untreated control conditions.

\subsection{ATP measurements}


The ATP content was assessed using the bioluminescence kit ATPLite (Perkin Elmer,

Zaventem, BE) according to the procedure provided by the manufacturer. Results are expressed as nmol $/ 10^{6}$ cells.

\subsection{Immunoblotting assays}

At the indicated times, cells were washed twice with ice-cold PBS and then resuspended in an RIPA lysis buffer supplemented with 1\% Protease Inhibitor Cocktail (Sigma-Aldrich) and 3\% Phosphatase Inhibitor Cocktail (Calbiochem). The samples were kept on ice for $5 \mathrm{~min}$. They were then centrifuged at $13,000 \times \mathrm{g}$ for $15 \mathrm{~min}$ at $4^{\circ} \mathrm{C}$ or sonicated for 15 seconds for the detection of $\gamma-\mathrm{H} 2 \mathrm{AX}$. Supernatants or sonicated samples were collected and then stored at $-80^{\circ} \mathrm{C}$. Equal amounts of proteins were subjected to SDS-PAGE (6-15\% separating gel) followed by electroblot to nitrocellulose membranes. The membranes were blocked for 1 hour in TBS buffer ( $\mathrm{pH} 7.4)$ containing $5 \%$ powdered milk protein and then incubated overnight at $4^{\circ} \mathrm{C}$ with the appropriate antibody. Antibody against PAR was obtained from BD Biosciences Pharmingen (Franklin Lakes, NJ). Rabbit polyclonal antibody against phospho-H2AX ( $\gamma$ H2AX) was from Upstate (Billerica, MA), against GRP94 from Chemicon International (Temecula, CA), and against Phospho-eIF2a (Ser51) from Cell Signaling Technology (Danvers, MA). After washing, membranes were exposed for $60 \mathrm{~min}$ at room temperature to a secondary antibody from Chemicon International (Temecula, CA) linked to HRP or alkaline phosphatase. Finally, the protein bands were detected by chemiluminescence.

\section{7. $\left[\mathrm{Ca}^{2+}\right]_{c}$ measurements by microspectrofluorimetry}

Measurement of $\left[\mathrm{Ca}^{2+}\right]_{\mathrm{c}}$ was performed as previously described [38] with some modifications. The cells, plated on glass coverslips, were incubated with $1 \mu \mathrm{M}$ fura- $2 \mathrm{AM}$ in medium at $37^{\circ} \mathrm{C}$ for $30 \mathrm{~min}$, then washed for $10 \mathrm{~min}$ in $\mathrm{HBSS}$ at $20^{\circ} \mathrm{C}$ and maintained at room temperature in the same saline solution until the fluorescence was measured. The coverslip was then mounted in a Pecon microscope chamber $(1 \mathrm{ml})$. When indicated, cells were 
superfused with HBSS without calcium and with $200 \mu \mathrm{M}$ EGTA ( 1 ml. minute $\left.{ }^{-1}\right)$ allowing quick changes of extracellular solution. Fura-2 loaded cells were alternately excited at 340 and $380 \mathrm{~nm}$ using a Lambda DG-4 Ultra High Speed Wavelength Switcher (Sutter Instrument, Novato, CA) coupled to a Zeiss Axivert 200M inverted microscope (x 20 fluorescence objective) (Zeiss Belgium, Zaventem, BE). Images were acquired every second at different times with a Zeiss Axiocam camera coupled with a $510 \mathrm{~nm}$ emission filter and analyzed by the Axiovision software. Fluorescence intensity was recorded over the entire surface of each cell and intracellular calcium concentration was evaluated from the ratio of the fluorescence emission intensities excited at the two wavelengths. Calibration of fura- 2 was performed as described by Palmer et al., [39] except that cells were treated with $10 \mu \mathrm{M}$ ionomycin and $10 \mathrm{mM}$ EGTA in $\mathrm{Ca}^{2+}$-free $\mathrm{HBSS}$ to obtain $\mathrm{Rmin}$ and with $20 \mathrm{mM} \mathrm{Ca}^{2+}$ in HBSS to obtain Rmax. The standard equation: $\mathrm{K}_{\mathrm{d}}[(\mathrm{R}-\mathrm{Rmin}) /(\mathrm{Rmax}-\mathrm{R})] \cdot \mathrm{S}_{\mathrm{f}} / \mathrm{S}_{\mathrm{b}}$ was used to convert the fura- 2 ratio to $\left[\mathrm{Ca}^{2+}\right]_{\mathrm{c}}$, where $\mathrm{S}_{\mathrm{f}}$ and $\mathrm{S}_{\mathrm{b}}$ are the emission intensities at $380 \mathrm{~nm}$ for $\mathrm{Ca}^{2+}$-free and $\mathrm{Ca}^{2+}$-bound fura-2, respectively. In situ $\mathrm{Rmin}$ and $\mathrm{Rmax}$ values were multiplied by 0.85 to adjust for the minimum viscosity effect.

\section{8. $\left[\mathrm{Ca}^{2+}\right]_{\mathrm{c}}$ measurements using a fluorescence microplate reader}

This method was adapted from the article by Robinson et al., [40]. For $\left[\mathrm{Ca}^{2+}\right]_{\mathrm{c}}$ measurement, MCF-7 cells were seeded onto 96-well plates at a density of 25000 cells/well in $100 \mu 1$ of growth media. At subconfluence, the culture medium was replaced with FBS free media for $24 \mathrm{~h}$ to attempt to synchronize cells into a nonproliferative stage. MCF-7 cells were then loaded with $25 \mu \mathrm{M}$ fluo-3/AM in medium at $37^{\circ} \mathrm{C}$ for $30 \mathrm{~min}$ followed by $30 \mathrm{~min}$ at room temperature to minimize dye leakage and sequestration into intracellular organelles. After loading, cells were washed twice with $200 \mu \mathrm{HBSS}$ in order to remove excess fluorescent dye. Cells were then treated for different durations with various compounds in normal or calcium-free medium. Cells were washed twice with $200 \mu \mathrm{l}$ HBSS and then $100 \mu 1$ 
HBSS/well was added. The fluorescence intensity of fluo-3 was measured at an excitation wavelength of $485 \mathrm{~nm}$ and an emission wavelength of $520 \mathrm{~nm}$. Relative changes in calcium concentration using fluo-3 were determined by calculations of $\Delta \mathrm{F} / \mathrm{F} 0$, where $\Delta \mathrm{F} / \mathrm{F} 0=(\mathrm{Ft}-$ F0)/F0. Ft represents the fluorescence reading at each time point and F0 the initial fluorescence. For live-cell imaging, cells were seeded on a 4-well Lab-Tek chamber glass slide (Nunc, Naperville, IL), at a density of 50000 cells/well, cultured for 3 days, and treated as described for the quantification protocol.

\subsection{Oxyblot}

The immunoblot detection of carbonyl groups introduced into proteins by oxidative reactions was achieved using OxyBlot ${ }^{\mathrm{TM}}$ Protein Oxidation Detection Kit (Chemicon International, Temecula, CA, USA) according to the procedure provided by the manufacturer.

\subsection{Data analysis}

Results are expressed as means \pm standard deviation (SD). Differences among the experimental groups were analysed using one-way ANOVA followed, where appropriate, by a Tukey post-hoc test. These tests were performed using GraphPad Prism software (GraphPad Software San Diego, CA, USA). P values less than 0.05 were considered statistically significant.

\section{Results}

\subsection{Oxidative stress induces calcium increase in MCF-7 cells}

To investigate the acute effects of the pro-oxidant association of Asc/Men on $\left[\mathrm{Ca}^{2+}\right]_{\mathrm{c}}$ in $\mathrm{MCF}-$ 7 cells, fluo-3/AM loaded cells were exposed to Asc/Men for different time periods. The results presented in Fig. $1 A$ show that incubation with Asc/Men resulted in a slow increase in $\left[\mathrm{Ca}^{2+}\right]_{\mathrm{c}}$ in MCF-7 cells. Using microspectrofluorimetry with the ratiometric fluorescent probe, 
fura-2, AM, the increase in $\left[\mathrm{Ca}^{2+}\right]_{\mathrm{c}}$ was estimated to be close to $50 \%$ after $90 \mathrm{~min}$ (Fig. $1 \mathrm{~B}$ ). To verify whether the calcium mobilization was not due to membrane disruption, $\left[\mathrm{Ca}^{2+}\right]_{\mathrm{c}}$ and propidium iodide permeation were simultaneously measured after different durations of exposure to Asc/Men (Fig. 1C). This experiment revealed that calcium increase was triggered during the first hour of Asc/Men treatment and that, in contrast, propidium iodide uptake was observed after more than $4 \mathrm{~h}$. This clearly indicates that the increase in $\left[\mathrm{Ca}^{2+}\right]_{\mathrm{c}}$ largely preceded signs of cell death.

\section{2. [Ca2+]c increase is unlikely to be associated with activation of calcium-dependent death pathways}

Since Asc/Men triggered disruption of calcium homeostasis in MCF-7 cells, we then explored the influence of oxidative stress on different pathways associated with calcium disturbance. First, calcium itself may directly activate proteases (i.e., calpains) or calmodulin-associated enzymes, which may themselves be involved in the cytotoxic processes of oxidative stress. Moreover, perturbations of intracellular calcium can activate mitochondrial apoptotic pathways, including the opening of the mitochondrial permeability transition pore (mPTP). We therefore tested the influence of inhibitors of these pathways on the loss of cell viability observed after Asc/Men treatment. W7 $(25 \mu \mathrm{M})$, calpeptin $(10 \mu \mathrm{M}), \mathrm{Ru} 360(5 \mu \mathrm{M})$, and cyclosporine $\mathrm{A}(5 \mu \mathrm{M})$ were chosen to inhibit calcium-dependent proteases, calmodulin, entry of calcium into the mitochondria, and mPTP opening, respectively ( $1 \mathrm{~h}$ pre-incubation). Unlike the antioxidant, NAC, none of these compounds had any protective effect on oxidative stress-mediated decrease in cell viability (Fig. $2 A$ and $B$ ). We also hypothesized that the DNA strand breaks induced by Asc/Men (as we have previously shown [31, 33]) could be the result of calcium-dependent endonuclease activation. To study this hypothesis, we tested the effects of $1 \mathrm{~h}$ pre-incubation with $100 \mu \mathrm{M}$ aurintricarboxylic acid (a calcium-dependent endonuclease inhibitor) on the loss of viability observed in MCF-7 cells after Asc/Men exposure; this 
inhibitor had no measurable effect (Fig. 2A). To examine whether extracellular calcium chelation or depletion could affect Asc/Men cytotoxicity, we then measured MCF-7 cell viability after $4 \mathrm{~h}$ of exposure to Asc/Men, in media with and without calcium, or with $2 \mathrm{mM}$ of the extracellular calcium chelator, EGTA (Fig. 2C). Results from this experiment demonstrated that extracellular calcium depletion or chelation had no protective effects against Asc/Men. Taken together, our results show that the increase in intracellular calcium after administration of Asc/Men is unlikely to be involved in the mechanisms leading to MCF-7 death.

\subsection{Effect of BAPTA-AM, an intracellular calcium chelator on Asc/Men cytotoxic pathways.}

An intracellular calcium chelator, BAPTA-AM, was also used to explore the importance of an increase in cytosolic calcium on the cytotoxic pathways of Asc/Men. In our model, this chelator appeared to have a broad protective action, as shown by its concentration-dependent protection against the decrease in cell viability induced by Asc/Men exposure (Fig. 3A). However, since BAPTA-AM has been previously shown to chelate iron, and potentially interferes with Fenton's reaction $[41,42]$, we decided to identify at what level BAPTA-AM acts. Our results reveals that BAPTA-AM could prevent against all features of Asc/Men cytotoxicity, including decreases in ATP, PARP activation, DNA fragmentation, ER stress and even protein oxidation (Fig. $3 B, C$ and $D$ ). This suggests that the protective effect of BAPTA-AM observed in our model is most probably mediated by its capacity to interfere with pro-oxidative mechanisms, rather than by its ability to chelate calcium.

\subsection{ATP decrease and calcium release in MCF-7 cells exposed to oxidative stress}

Oxidative stress usually induces a rapid and marked decrease in cellular ATP. Among the consequences of this effect, the decrease in ATP may also be associated with ATP-dependent calcium channel dysfunction, a process potentially involved in the increase in $\left[\mathrm{Ca}^{2+}\right]_{\mathrm{c}}$ observed in MCF-7 cells exposed to oxidative stress. We, therefore, decided to explore the 
potential links between ATP depletion and increase in $\left[\mathrm{Ca}^{2+}\right]_{\mathrm{c}}$ during Asc/Men treatment. As shown in Fig. 4A, Asc/Men treatment induced a fast and dramatic decrease in ATP in MCF-7 cells. The glycolysis inhibitor, iodoacetate, was then used to mimic the decrease in cellular ATP level observed during Asc/Men treatment. As shown in Fig. 4B, exposure to $100 \mu \mathrm{M}$ iodoacetate resulted in a reduction in ATP level from $20.6 \pm 0.8$ to $8.6 \pm 0.2 \mathrm{nmol} / 10^{6}$ cells after 90 min. This decrease in ATP was not accompanied by the same increase in $\left[\mathrm{Ca}^{2+}\right]_{\mathrm{c}}$ observed after 90 min of Asc/Men treatment (Fig. 4C), confirming that the large increase in calcium observed in oxidative stress exposed MCF-7 cells was not due to ATP depletion.

\subsection{Oxidative stress partially releases $\left[\mathrm{Ca}^{2+}\right]_{\text {er }}$ and induces ER stress in MCF-7 cells}

Since disturbance in cytosolic calcium is unlikely to be involved in the pathways leading to the loss of cell viability induced by Asc/Men, we further studied the effect of Asc/Mengenerated oxidative stress on the ER, the major cellular store of calcium. We first measured whether the response of MCF-7 cells to TG (TG irreversibly inhibits (sarco)endoplasmic reticulum $\mathrm{Ca}^{2+}$-ATPase (SERCA) and depletes ER calcium stores) could be altered by Asc/Men. To this end, untreated control cells (Fig. 5A) or cells pre-treated with Asc/Men for 90 min (Fig. 5B) were stimulated with TG $(1 \mu \mathrm{M})$ after extracellular calcium removal and $\left[\mathrm{Ca}^{2+}\right]_{\mathrm{c}}$ was measured. The results showed that the TG-driven increase in $\left[\mathrm{Ca}^{2+}\right]_{\mathrm{c}}$ was attenuated when cells were pre-treated with Asc/Men. Indeed, Fig. $5 C$ shows that the response to TG was decreased by approximately $45 \%(124.8 \pm 8.0 \mathrm{nM}$ for control and $68.9 \pm 4.7 \mathrm{nM}$ for Asc/Men conditions). These findings suggest that Asc/Men slowly depletes calcium from the ER. Second, since $\left[\mathrm{Ca}^{2+}\right]_{\text {er }}$ release can be both a cause and a consequence of ER stress, we explored whether ER stress was associated with Asc/Men treatment. We measured levels of eIF2 phosphorylation, a central component of the control arm of the UPR, and of GRP94 protein abundance, one of the major ER chaperones that are transcriptionally upregulated during ER stress. Fig. $5 D$ shows that $1 \mathrm{~h}$ of Asc/Men treatment induced eIF2 phosphorylation, 
which increased dramatically after 2 and $4 \mathrm{~h}$. The appearance of P-eIF2 was associated with the increase in GRP94 protein. These results clearly indicate that oxidative stress induces ER stress in MCF-7 cells, concomitant with ER calcium release.

\subsection{Involvement of ER calcium emptying in ER stress triggered by oxidative stress and cell death}

Our results confirm the observations that Asc/Men triggers ER stress and ER calcium release. We then decided to address the issue of whether TG-induced complete calcium release had a putative effect on the ER stress induction observed in cells exposed to Asc/Men (Fig. 6A). For this experiment, ascorbate and menadione were used at the lowest concentrations of $0.5 \mathrm{mM}$ and $5 \mu \mathrm{M}$, respectively. At this concentration, Asc/Men induced eIF2 phosphorylation after 2 $\mathrm{h}$ of treatment, while TG triggered this event after $0.5 \mathrm{~h}$ (Fig. $6 A$ ). Surprisingly, the combination of Asc/Men and TG dramatically increased the appearance of P-eIF2 after just 30 min of treatment. These results demonstrate that oxidative stress and calcium release are two ER stress-inducing factors that synergize when applied together and that calcium release is not likely to be the only process responsible for UPR activation during oxidative stress. Regarding GRP94 protein levels, TG caused GRP94 overexpression only after $24 \mathrm{~h}$ (Fig. 6A). Since various authors have proposed that ER stress is one of the oxidative pathways leading to cell death, we then decided to address the question of whether the potentiating effect of TG on the ER stress induced by Asc/Men was also accompanied by an increase in cell death. For this purpose, cell survival was measured in cells exposed for different durations to TG, Asc/Men $0.5 / 5$, or both. Fig. $6 B$ shows that incubation with Asc/Men $0.5 / 5$ or TG resulted in a slow reduction in MCF-7 cell survival, reaching levels of $52.6 \pm 7.3$ and $66.4 \pm 9.5$ after $24 \mathrm{~h}$, respectively. The combination of the two treatments resulted in enhancement of cell death, especially in the 6th hour of treatment $(\mathrm{p}<0.01$ for TG + Asc/Men $0.5 / 5$ compared to TG 
alone and $\mathrm{p}<0.05$ compared to Asc/Men). This experiment supports a role of ER stress in processes of oxidative stress-induced cell death.

Previous studies have revealed that TG exposure is generally associated with DNA fragmentation [43-45]. Asc/Men treatment also triggers this event, which results in poly(ADP ribose) polymerase (PARP) activation and $\mathrm{NAD}^{+}$depletion (Fig. 3 and Verrax et al., 2004 and 2007 [31, 33]). We, therefore, assessed the effects of TG and Asc/Men treatment on histone H2AX phosphorylation, a marker of DNA damage in the form of double-strand breaks. As presented in Fig. $6 C, 4 \mathrm{~h}$ of treatment with TG and Asc/Men 0.5/5 induced the appearance of $\gamma-\mathrm{H} 2 \mathrm{AX}$ (the phosphorylated form) only when both treatments were applied together, demonstrating that increased calcium release and consecutive ER stress also potentiate oxidative stress-induced DNA fragmentation.

\section{Discussion}

The present study was designed to elucidate the roles of disturbances in calcium homeostasis and of ER stress in oxidative stress-associated death in MCF-7 cells. Our results reveal that Asc/Men-induced oxidative stress elicits $\left[\mathrm{Ca}^{2+}\right]_{\mathrm{er}}$ release, ER stress and increase in $\left[\mathrm{Ca}^{2+}\right]_{\mathrm{c}}$ after drug exposure. In this model, ER stress and associated $\left[\mathrm{Ca}^{2+}\right]_{\mathrm{er}}$ emptying, but not alterations in $\left[\mathrm{Ca}^{2+}\right]_{\mathrm{c}}$, appear to have a role in cell death induction.

The first finding of our study is that the pro-oxidant association of Asc/Men induces a slow increase in cytosolic calcium. Use of iodoacetate in order to mimic Asc/Men-induced depletion in ATP did not trigger cytoplasmic calcium overload, suggesting that ATP depletion was not the cause of the large increase in intracellular calcium observed during oxidative exposure. One goal of our study was to clarify the link between the identified oxidative 
increase in cytosolic calcium and MCF-7 cell death. Various data provide evidence that alterations in $\left[\mathrm{Ca}^{2+}\right]_{\mathrm{c}}$ are not involved in oxidative toxicity: First, using specific inhibitors of pathways that have already been proposed to participate in calcium-mediated oxidative toxicity [5], we could not demonstrate any role of enzymes, such as proteases, calmodulinassociated enzymes or calcium-dependent endonucleases, in these processes. The potential involvement of mitochondria was also tested. Indeed, it is known that exposure of mitochondria to high calcium concentrations during oxidative stress results in their swelling and uncoupling. This phenomenon leads to a loss of maintenance of cellular ATP levels and finally to cell death by necrosis [46]. In our study, use of Ru360, a specific mitochondrial calcium uptake inhibitors (uniport transporter inhibitor) and cyclosporine A (a mPTP inhibitor) was not associated with any effect on Asc/Men toxicity. This suggests that mitochondrial calcium uptake was not involved in the toxicity in our model and contrasts with reports examining the role of mitochondrial permeability transition in the cytotoxicity of the pro-oxidant, tert-butylhydroperoxide [47]. Secondly, depleting or chelating extracellular calcium (by EGTA) was not protective against loss of cell viability during oxidative stress. Because EGTA, in addition to its effect on extracellular calcium, tends to draw intracellular calcium (as shown in Figs. $5 A$ and $B$ ), its lack of effect on cell viability can be considered as another argument against the involvement of altered $\left[\mathrm{Ca}^{2+}\right]_{\mathrm{c}}$ in oxidative toxicity. Furthermore, we found that media without calcium and with $200 \mu \mathrm{M}$ EGTA, could not preserve cell viability during Asc/Men exposure (not shown). This observation is in agreement with the report of Persoon-Rothert and colleagues in 1994 [48]. Thirdly, BAPTA$\mathrm{AM}$, one of the most used intracellular calcium chelator, was shown to protect cells from oxidative modifications during Asc/Men exposure (Fig. 3D). The protective effect of this chelator is generally the principal argument for a connection between $\left[\mathrm{Ca}^{2+}\right]_{\mathrm{c}}$ deregulation and oxidative injury. Our results suggest that BAPTA-AM may interact with pro-oxidative 
mechanisms in our model. However, it cannot be ruled out that BAPTA-AM could also chelate intracellular calcium, and protects cells in this way from oxidative toxicity. These are still speculations and need further study. It has been proposed that BAPTA-AM interferes with Fenton's reaction [41, 42] or may protect against a poorly defined pro-oxidative calciumassociated process, such as calcium-induced iron release [49] or ER stress-generated ROS production [50-52].

The typical profile of the intracellular calcium response identified in our study has also been observed in other cell lines exposed to $\mathrm{H}_{2} \mathrm{O}_{2}$, such as $\mathrm{HeLa}$, human erythrocytes and MDCK (a canine epithelial cell line) [53], CRI-G1 (an insulin-secreting cell line) [54] or pancreatic acinar cells $[14,55]$. However, to our knowledge, this is the first time this effect has been demonstrated in MCF-7 cells. Although high concentrations of $\mathrm{H}_{2} \mathrm{O}_{2}$ have been shown to induce a similar calcium response to that seen in our study, there is no consensus regarding the source of calcium, as highlighted and discussed in the study by Castro et al., [53]. These authors reported that the increase in intracellular calcium increase came largely from a cytosolic unrecognized source. Although it was not the main goal of our study, we found that ER calcium release could partly explain the elevation in $\left[\mathrm{Ca}^{2+}\right]_{\mathrm{c}}$ in MCF-7 cells exposed to oxidative stress. This is in agreement with previous reports exploring the effects of $\mathrm{H}_{2} \mathrm{O}_{2}$ exposure on modulation of calcium homeostasis [13, 14].

Oxidative stress encompasses a number of ER stress inducing factors, including calcium emptying (presumably by inhibition of calcium ATPase $[15,16,56]$ ), or direct oxidative damage to newly folded proteins or proteins of the ER machinery. However, the relative contributions of these events in oxidative stress-induced ER stress are not known. Furthermore, the relationship between oxidative stress and ER stress is a matter of debate, because activation of the UPR can also result in ROS generation [50-52]. In our study, we found that pro-oxidant Asc/Men treatment induced the translational control arm of the UPR 
(by enhancing eIF2 phosphorylation) and upregulation of ER folding capacity (by the increase in GRP94 protein, one of the major ER chaperones). These events were accompanied by a slow leakage of $\left[\mathrm{Ca}^{2+}\right]_{\mathrm{er}}$. Given these results, we then focused on the potential link between ER calcium release and ER stress activation. For this purpose, TG was used as an UPR inducer to trigger irreversible calcium release from the ER. We showed that TG and consequent calcium emptying also induced eIF2 phosphorylation shortly after addition of TG. This effect was weaker than that observed after exposure of cells to ascorbate or menadione at concentrations of $1 \mathrm{mM}$ and $10 \mu \mathrm{M}$, respectively (Fig. $5 D$ and $6 A$ ), suggesting that the $\left[\mathrm{Ca}^{2+}\right]_{\mathrm{er}}$ leak was not sufficient to explain the oxidative stress-induced UPR activation in our model. Moreover, the combination of oxidative stress and TG-induced ER $\left[\mathrm{Ca}^{2+}\right]_{\text {er }}$ release resulted in a greater and more rapid eIF2 phosphorylation, in a synergistic manner. This clearly demonstrates that ER calcium depletion is not the main process responsible for ER stress induction by oxidative stress.

The involvement of ER stress and consequent UPR activation in the processes of oxidative stress-induced cell death has not been elucidated. Here, we showed that $\left[\mathrm{Ca}^{2+}\right]_{\mathrm{er}}$ release potentiates Asc/Men-associated ER stress and cytotoxicity. This suggests that ER stress is involved in the processes of oxidative stress-induced cell death. Moreover, this is in agreement with previous reports which showed that increasing ER folding capacity (by transfection with an ER chaperone) or decreasing UPR can markedly attenuate ROS-induced apoptosis in other cell lines [19, 24-26]. These findings also confirm results from the study by Hung et al., in which protection of ER calcium release by overexpression of the major ER $\mathrm{Ca}^{2+}$-binding protein, calreticulin, protected against $\mathrm{H}_{2} \mathrm{O}_{2}$-induced cell injury [26]. In addition, in our study, $\left[\mathrm{Ca}^{2+}\right]_{\mathrm{er}}$ emptying also potentiated Asc/Men-induced DNA fragmentation and associated histone H2AX phosphorylation, suggesting that ER stress could 
represent one of the pathways leading to this event; this observation also underlines the capacity of TG to trigger DNA fragmentation, as shown by others [43-45, 57]. In conclusion, in this study we report the major role of disrupted ER calcium homeostasis on Asc/Men oxidative toxicity in MCF-7 cells and highlight the relative contribution of ER stress in this process. Our results confirm the pro-oxidant activity of the association of ascorbate and menadione $[29-33,35,58,59]$ and suggest that it could represent an interesting therapy in tumors in which increased ER folding capacity is associated with cancer resistance.

\section{Acknowledgements}

The authors would like to thank Isabelle Blave and Véronique Allaeys for their excellent technical assistance. This work was supported by grants from Televie and the Belgian Fonds National de la Recherche Scientifique (7.4566.07) and and by grant ARC 05/10-328 from the General Direction of Scientific Research of the French Community of Belgium. Raphaël Beck is a FRIA recipient. Julien Verrax and Nicolas Tajeddine are FNRS Post-Doctoral Researchers, and Nicolas Dejeans is a Televie-FNRS Post-Doctoral Researcher. We dedicate this work to the late Dr. Henryk Taper, in honor of his pioneering studies on the association of ascorbate and menadione. 


\section{References}

[1] Orrenius S, Zhivotovsky B, Nicotera P. Regulation of cell death: the calciumapoptosis link. Nat Rev Mol Cell Biol 2003;4:552-65.

[2] Nicotera P, Orrenius S. Ca2+ and cell death. Ann N Y Acad Sci 1992;648:17-27.

[3] Berridge MJ, Bootman MD, Lipp P. Calcium--a life and death signal. Nature $1998 ; 395: 645-8$.

[4] Trump BF, Berezesky IK. Calcium-mediated cell injury and cell death. FASEB J 1995;9:219-28.

[5] Ermak G, Davies KJ. Calcium and oxidative stress: from cell signaling to cell death. Mol Immunol 2002;38:713-21.

[6] Zhang K, Kaufman RJ. Protein folding in the endoplasmic reticulum and the unfolded protein response. Handb Exp Pharmacol 2006:69-91.

[7] Schroder M, Kaufman RJ. The mammalian unfolded protein response. Annu Rev Biochem 2005;74:739-89.

[8] Ni M, Lee AS. ER chaperones in mammalian development and human diseases. FEBS Lett 2007;581:3641-51.

[9] Dong D, Ko B, Baumeister P, Swenson S, Costa F, Markland F, et al. Vascular targeting and antiangiogenesis agents induce drug resistance effector GRP78 within the tumor microenvironment. Cancer Res 2005;65:5785-91.

[10] Pyrko P, Schonthal AH, Hofman FM, Chen TC, Lee AS. The unfolded protein response regulator GRP78/BiP as a novel target for increasing chemosensitivity in malignant gliomas. Cancer Res 2007;67:9809-16. 
[11] Malhotra JD, Kaufman RJ. Endoplasmic reticulum stress and oxidative stress: a vicious cycle or a double-edged sword? Antioxid Redox Signal 2007;9:2277-93.

[12] Tagliarino C, Pink JJ, Dubyak GR, Nieminen AL, Boothman DA. Calcium is a key signaling molecule in beta-lapachone-mediated cell death. J Biol Chem 2001;276:19150-9.

[13] Doan TN, Gentry DL, Taylor AA, Elliott SJ. Hydrogen peroxide activates agonistsensitive $\mathrm{Ca}(2+)$-flux pathways in canine venous endothelial cells. Biochem $\mathbf{J}$ 1994;297 ( Pt 1):209-15.

[14] Bruce JI, Elliott AC. Oxidant-impaired intracellular Ca2+ signaling in pancreatic acinar cells: role of the plasma membrane Ca2+-ATPase. Am J Physiol Cell Physiol 2007;293:C938-50.

[15] Kaplan P, Babusikova E, Lehotsky J, Dobrota D. Free radical-induced protein modification and inhibition of Ca2+-ATPase of cardiac sarcoplasmic reticulum. Mol Cell Biochem 2003;248:41-7.

[16] Moreau VH, Castilho RF, Ferreira ST, Carvalho-Alves PC. Oxidative damage to sarcoplasmic reticulum Ca2+-ATPase AT submicromolar iron concentrations: evidence for metal-catalyzed oxidation. Free Radic Biol Med 1998;25:554-60.

[17] van der Vlies D, Makkinje M, Jansens A, Braakman I, Verkleij AJ, Wirtz KW, et al. Oxidation of ER resident proteins upon oxidative stress: effects of altering cellular redox/antioxidant status and implications for protein maturation. Antioxid Redox Signal 2003;5:381-7.

[18] Merksamer PI, Trusina A, Papa FR. Real-time redox measurements during endoplasmic reticulum stress reveal interlinked protein folding functions. Cell 2008;135:933-47. 
[19] Yokouchi M, Hiramatsu N, Hayakawa K, Okamura M, Du S, Kasai A, et al. Involvement of selective reactive oxygen species upstream of proapoptotic branches of unfolded protein response. J Biol Chem 2008;283:4252-60.

[20] Min SK, Lee SK, Park JS, Lee J, Paeng JY, Lee SI, et al. Endoplasmic reticulum stress is involved in hydrogen peroxide induced apoptosis in immortalized and malignant human oral keratinocytes. J Oral Pathol Med 2008;37:490-8.

[21] Harding HP, Zhang Y, Zeng H, Novoa I, Lu PD, Calfon M, et al. An integrated stress response regulates amino acid metabolism and resistance to oxidative stress. Mol Cell $2003 ; 11: 619-33$

[22] Baker KM, Chakravarthi S, Langton KP, Sheppard AM, Lu H, Bulleid NJ. Low reduction potential of Erolalpha regulatory disulphides ensures tight control of substrate oxidation. EMBO J 2008;27:2988-97.

[23] Gorlach A, Klappa P, Kietzmann T. The endoplasmic reticulum: folding, calcium homeostasis, signaling, and redox control. Antioxid Redox Signal 2006;8:1391-418.

[24] Yokouchi M, Hiramatsu N, Hayakawa K, Kasai A, Takano Y, Yao J, et al. Atypical, bidirectional regulation of cadmium-induced apoptosis via distinct signaling of unfolded protein response. Cell Death Differ 2007;14:1467-74.

[25] Sanson M, Auge N, Vindis C, Muller C, Bando Y, Thiers JC, et al. Oxidized lowdensity lipoproteins trigger endoplasmic reticulum stress in vascular cells: prevention by oxygen-regulated protein 150 expression. Circ Res 2009;104:328-36.

[26] Hung CC, Ichimura T, Stevens JL, Bonventre JV. Protection of renal epithelial cells against oxidative injury by endoplasmic reticulum stress preconditioning is mediated by ERK1/2 activation. J Biol Chem 2003;278:29317-26.

[27] Kadara H, Lacroix L, Lotan D, Lotan R. Induction of endoplasmic reticulum stress by the pro-apoptotic retinoid $\mathrm{N}$-(4-hydroxyphenyl)retinamide via a reactive oxygen 
[30] Taper HS, de Gerlache J, Lans M, Roberfroid M. Non-toxic potentiation of cancer chemotherapy by combined C and K3 vitamin pre-treatment. Int J Cancer $1987 ; 40: 575-9$.

[31] Verrax J, Vanbever S, Stockis J, Taper H, Calderon PB. Role of glycolysis inhibition and poly(ADP-ribose) polymerase activation in necrotic-like cell death caused by ascorbate/menadione-induced oxidative stress in K562 human chronic myelogenous leukemic cells. Int J Cancer 2007;120:1192-7.

[32] Verrax J, Stockis J, Tison A, Taper HS, Calderon PB. Oxidative stress by ascorbate/menadione association kills K562 human chronic myelogenous leukaemia cells and inhibits its tumour growth in nude mice. Biochem Pharmacol 2006;72:67180.

[33] Verrax J, Cadrobbi J, Marques C, Taper H, Habraken Y, Piette J, et al. Ascorbate potentiates the cytotoxicity of menadione leading to an oxidative stress that kills cancer cells by a non-apoptotic caspase-3 independent form of cell death. Apoptosis 2004;9:223-33

[34] Verrax J, Calderon PB. The controversial place of vitamin C in cancer treatment. Biochem Pharmacol 2008;76:1644-52. 
[35] Verrax J, Delvaux M, Beghein N, Taper H, Gallez B, Buc Calderon P. Enhancement of quinone redox cycling by ascorbate induces a caspase- 3 independent cell death in human leukaemia cells. An in vitro comparative study. Free Radic Res 2005;39:64957.

[36] Beck R, Verrax J, Dejeans N, Taper H, Calderon PB. Menadione Reduction by Pharmacological Doses of Ascorbate Induces an Oxidative Stress That Kills Breast Cancer Cells. Int J Toxicol 2009;28:33-42.

[37] Mosmann T. Rapid colorimetric assay for cellular growth and survival: application to proliferation and cytotoxicity assays. J Immunol Methods 1983;65:55-63.

[38] Pigozzi D, Ducret T, Tajeddine N, Gala JL, Tombal B, Gailly P. Calcium store contents control the expression of TRPC1, TRPC3 and TRPV6 proteins in LNCaP prostate cancer cell line. Cell Calcium 2006;39:401-15.

[39] Palmer AE, Jin C, Reed JC, Tsien RY. Bcl-2-mediated alterations in endoplasmic reticulum $\mathrm{Ca} 2+$ analyzed with an improved genetically encoded fluorescent sensor. Proc Natl Acad Sci U S A 2004;101:17404-9.

[40] Robinson JA, Jenkins NS, Holman NA, Roberts-Thomson SJ, Monteith GR. Ratiometric and nonratiometric $\mathrm{Ca} 2+$ indicators for the assessment of intracellular free $\mathrm{Ca} 2+$ in a breast cancer cell line using a fluorescence microplate reader. J Biochem Biophys Methods 2004;58:227-37.

[41] Britigan BE, Rasmussen GT, Cox CD. Binding of iron and inhibition of irondependent oxidative cell injury by the "calcium chelator" 1,2-bis(2aminophenoxy)ethane N,N,N',N'-tetraacetic acid (BAPTA). Biochem Pharmacol 1998;55:287-95. 
[42] Glickstein H, El RB, Shvartsman M, Cabantchik ZI. Intracellular labile iron pools as direct targets of iron chelators: a fluorescence study of chelator action in living cells. Blood 2005;106:3242-50.

[43] Nakano T, Watanabe H, Ozeki M, Asai M, Katoh H, Satoh H, et al. Endoplasmic reticulum $\mathrm{Ca} 2+$ depletion induces endothelial cell apoptosis independently of caspase12. Cardiovasc Res 2006;69:908-15.

[44] Wei H, Wei W, Bredesen DE, Perry DC. Bcl-2 protects against apoptosis in neuronal cell line caused by thapsigargin-induced depletion of intracellular calcium stores. J Neurochem 1998;70:2305-14.

[45] Nguyen HN, Wang C, Perry DC. Depletion of intracellular calcium stores is toxic to SH-SY5Y neuronal cells. Brain Res 2002;924:159-66.

[46] Halestrap AP. Calcium, mitochondria and reperfusion injury: a pore way to die. Biochem Soc Trans 2006;34:232-7.

[47] Lemasters JJ, Theruvath TP, Zhong Z, Nieminen AL. Mitochondrial calcium and the permeability transition in cell death. Biochim Biophys Acta 2009.

[48] Persoon-Rothert M, Egas-Kenniphaas JM, van der Valk-Kokshoorn EJ, Buys JP, van der Laarse A. Oxidative stress-induced perturbations of calcium homeostasis and cell death in cultured myocytes: role of extracellular calcium. Mol Cell Biochem 1994;136:1-9.

[49] Kim HJ, Kim SG. Alterations in cellular $\mathrm{Ca}(2+)$ and free iron pool by sulfur amino acid deprivation: the role of ferritin light chain down-regulation in prooxidant production. Biochem Pharmacol 2002;63:647-57.

[50] Haynes CM, Titus EA, Cooper AA. Degradation of misfolded proteins prevents ERderived oxidative stress and cell death. Mol Cell 2004;15:767-76. 
[51] Malhotra JD, Miao H, Zhang K, Wolfson A, Pennathur S, Pipe SW, et al. Antioxidants reduce endoplasmic reticulum stress and improve protein secretion. Proc Natl Acad Sci U S A 2008;105:18525-30.

[52] Santos CX, Tanaka LY, Wosniak JJ, Laurindo FR. Mechanisms and Implications of Reactive Oxygen Species Generation During the Unfolded Protein Response: Roles of Endoplasmic Reticulum Oxidoreductases, Mitochondrial Electron Transport and NADPH Oxidase. Antioxid Redox Signal 2009.

[53] Castro J, Bittner CX, Humeres A, Montecinos VP, Vera JC, Barros LF. A cytosolic source of calcium unveiled by hydrogen peroxide with relevance for epithelial cell death. Cell Death Differ 2004;11:468-78.

[54] Herson PS, Lee K, Pinnock RD, Hughes J, Ashford ML. Hydrogen peroxide induces intracellular calcium overload by activation of a non-selective cation channel in an insulin-secreting cell line. J Biol Chem 1999;274:833-41.

[55] Baggaley EM, Elliott AC, Bruce JI. Oxidant-induced inhibition of the plasma membrane Ca2+-ATPase in pancreatic acinar cells: role of the mitochondria. Am J Physiol Cell Physiol 2008;295:C1247-60.

[56] Castilho RF, Carvalho-Alves PC, Vercesi AE, Ferreira ST. Oxidative damage to sarcoplasmic reticulum $\mathrm{Ca}(2+)$-pump induced by $\mathrm{Fe} 2+/ \mathrm{H} 2 \mathrm{O} 2 /$ ascorbate is not mediated by lipid peroxidation or thiol oxidation and leads to protein fragmentation. Mol Cell Biochem 1996;159:105-14.

[57] Pigozzi D, Tombal B, Ducret T, Vacher P, Gailly P. Role of store-dependent influx of $\mathrm{Ca} 2+$ and efflux of $\mathrm{K}+$ in apoptosis of CHO cells. Cell Calcium 2004;36:421-30.

[58] Taper HS, Keyeux A, Roberfroid M. Potentiation of radiotherapy by nontoxic pretreatment with combined vitamins $\mathrm{C}$ and $\mathrm{K} 3$ in mice bearing solid transplantable tumor. Anticancer Res 1996;16:499-503. 
[59] Verrax J, Pedrosa RC, Beck R, Dejeans N, Taper H, Calderon PB. In situ modulation of oxidative stress: a novel and efficient strategy to kill cancer cells. Curr Med Chem 2009;16:1821-30.

\section{FIGURE LEGENDS}

Fig. 1 - Asc/Men exposure triggers increase in intracellular calcium. A, intracellular calcium levels were measured in living cells using the calcium indicator dye, fluo-3/AM. Cells were preincubated for $30 \mathrm{~min}$ at $37^{\circ} \mathrm{C}$ and for a further 30 minutes at room temperature with $25 \mu \mathrm{M}$ fluo-3/AM. Cells were then incubated at $37^{\circ} \mathrm{C}$ for different time periods in the presence of Asc/Men or in medium alone. For times 0 and $90 \mathrm{mn}$, cells were incubated for 90 $\mathrm{mn}$ in medium alone or in medium with Asc/Men. For times 30 and $60 \mathrm{mn}$, cells were incubated first with medium alone for 60 or $30 \mathrm{mn}$ respectively before Asc/Men (to achieve the final incubation time of $90 \mathrm{mn}$ between Fluo-3/AM loading and fluorescent measurement). Intracellular calcium levels were quantified using a fluorescence microplate reader as described under Section 2. Results are expressed as $\Delta \mathrm{F} / \mathrm{F} 0 . \boldsymbol{B}$, intracellular calcium concentration was measured in living cells exposed or not to Asc/Men for 90 min (80 cells for each group of 4 experiments), using the calcium indicator dye, fura-2, AM as described under Section 2. Results represent means \pm SEM. $\boldsymbol{C}$, cells were cultured in the presence of Asc/Men for different time periods (number of minutes indicated above). One hour before the end of the study, fluo-3/AM was added to the final concentration of $25 \mu \mathrm{M}$. At the end of the incubation, cells were washed and incubated in HBSS with propidium iodide (PI) just before acquisition of images of calcium and PI penetration.

\section{Fig. 2 - Influence of different inhibitors of calcium-associated death pathways or the} antioxidant NAC, on Asc/Men-induced loss of cell viability. Cell viability was measured by MTT tests as described under Section 2. $\boldsymbol{A}$ and $\boldsymbol{B}$, cells were preincubated with different 
inhibitors of: calmodulins (W-7, 25 $\mu \mathrm{M}, 1 \mathrm{~h}$ ), calpains (calpeptin [Calp], $10 \mu \mathrm{M}, 1 \mathrm{~h}$ ), calcium-dependent endonucleases (aurintricarboxylic acid [ATA], $100 \mu \mathrm{M}, 1 \mathrm{~h}$ ), mitochondrial calcium uptake (Ru360 $[\mathrm{Ru}], 5 \mu \mathrm{M}, 1 \mathrm{~h})$ or with a mitochondrial permeability transition pore (mPTP) inhibitor (cyclosporine-A [CsA], $5 \mu \mathrm{M}, 2 \mathrm{~h}$ ). When indicated, cells were pre-incubated with $\mathrm{N}$-acetyl cysteine (NAC, $3 \mathrm{mM}$ ) 15 min before Asc/Men. Cells were then incubated for $24 \mathrm{~h}(\boldsymbol{A})$ or $4 \mathrm{~h}(\boldsymbol{B})$ in the presence of $1 \mathrm{mM}$ ascorbate, $10 \mu \mathrm{M}$ of menadione (Asc/Men), and the different inhibitors. All results are shown as means \pm SD $(\mathrm{n}=2) . \boldsymbol{C}$, in order to obtain calcium-free conditions, media without calcium and without serum were used. Because serum depletion could itself influence the MTT test results, two experimental control conditions were added in which cells in serum-free medium were exposed or not to Asc/Men. Cells were incubated with or without Asc/Men for $4 \mathrm{~h}$, in the presence or absence of calcium, fetal bovine serum (FBS), or $2 \mathrm{mM}$ EGTA, then the MTT test was performed. Results are expressed as percentages of control and represent means \pm SD $(\mathrm{n}=3) . * * *$ statistically different $(\mathrm{p}<0.001)$ from the corresponding condition without Asc/Men.

Fig. 3 - Effect of BAPTA-AM in the process of Asc/Men induced cell death. $A$, cells were preincubated with different concentrations of BAPTA-AM for 15 min (BA), washed and incubated for $24 \mathrm{~h}$ in the presence of $1 \mathrm{mM}$ ascorbate and $10 \mu \mathrm{M}$ of menadione (Asc/Men). Cell viability was then assessed as described in the experimental procedure section. $\boldsymbol{B}$, BAPTA-AM and NAC inhibit the Asc/Men-induced decrease in ATP. Cells were preincubated with $10 \mu \mathrm{M}$ BAPTA-AM (BA) or $3 \mathrm{mM}$ of the antioxidant, NAC, for $15 \mathrm{~min}$, washed and incubated for the time indicated in the presence of $1 \mathrm{mM}$ ascorbate and $10 \mu \mathrm{M}$ of menadione (Asc/Men). The graph represents the ATP content of the cells, expressed as nmol $/ 10^{6}$ cells. $\boldsymbol{C}-\boldsymbol{D}$, cells were preincubated or not with 5 or $10 \mu \mathrm{M}$ BAPTA-AM or $3 \mathrm{mM}$ NAC for $15 \mathrm{~min}$. Cells were then washed and exposed to $1 \mathrm{mM}$ ascorbate and/or $10 \mu \mathrm{M}$ of 
menadione (Asc/Men) for the indicated times at $37^{\circ} \mathrm{C}$. Cells were then washed twice with PBS and lysed. DNA cleavage and activation of poly (ADP-ribose) polymerase (PARP) were evaluated by immunoblotting with antibodies that specifically recognize the phosphorylated form of histone $\mathrm{H} 2 \mathrm{AX}(\gamma-\mathrm{H} 2 \mathrm{AX})$ or poly-ADP-ribosylated proteins $(\boldsymbol{C})$. The presence of PeIF2 or levels of protein carbonylation were measured by western blot as described in the experimental procedures section $(\boldsymbol{D})$. Blots are representative examples of one of 3 independent experiments. For graphs, results are expressed as percentages of control and represent means $\pm \mathrm{SD}(\mathrm{n}=3)$. $* * *$ statistically different $(\mathrm{p}<0.001)$ from the corresponding condition without Asc/Men. Groups a, b and c were statistically different (at least $\mathrm{p}<0.05$ ).

Fig. 4 - Decrease in ATP was not associated with increase in intracellular calcium. $A-B$, cells were incubated for the indicated time in the presence of $1 \mathrm{mM}$ ascorbate and $10 \mu \mathrm{M}$ of menadione (Asc/Men) or with the glycolysis inhibitor, iodoacetate (Iodo), at a concentration of $100 \mu \mathrm{M}$. The ATP content of cells was then measured. The graphs represent the ATP content of the cells expressed as $\mathrm{nmol} / 10^{6}$ cells. $\boldsymbol{C}$, intracellular calcium levels were measured in live cells using the calcium indicator dye, fluo-3/AM, as described under Section 2. Cells were preincubated for 30 minutes at $37^{\circ} \mathrm{C}$ and then for a further 30 minutes at room temperature with $25 \mu \mathrm{M}$ fluo-3/AM. Cells were then incubated in the presence of $1 \mathrm{mM}$ ascorbate and $10 \mu \mathrm{M}$ of menadione (Asc/Men) or $100 \mu \mathrm{M}$ iodoacetate for 90 min at $37^{\circ} \mathrm{C}$. All results are shown as means \pm SD of 3 separate experiments and groups $\mathrm{a}, \mathrm{b}$ and $\mathrm{c}$ were statistically different (at least $\mathrm{p}<0.05$ ).

\section{Fig. 5 - Asc/Men exposure partially releases ER calcium and induces ER stress. $A, B$ and} $\boldsymbol{C}$, cytosolic calcium was assessed using the ratiometric dye, fura-2. The release of $\left[\mathrm{Ca}^{2+}\right]_{\mathrm{er}}$ by thapsigargin (TG) was compared in 80 Asc/Men-treated cells (from 4 experiments) versus 80 control (from 4 experiments) MCF-7 cells. Typical profile responses of a control cell and a cell pre-treated for $90 \mathrm{~min}$ with Asc/Men are presented in $\boldsymbol{A}$ and $\boldsymbol{B}$, respectively. Extracellular 
calcium was depleted 5 min before addition of TG $(1 \mu \mathrm{M})$ in order to avoid capacitative calcium influx. TG mediated $\left[\mathrm{Ca}^{2+}\right]_{\mathrm{c}}$ increase $\left(\Delta\left[\mathrm{Ca}^{2+}\right]\right)$ was quantified by the difference between maximal $\left[\mathrm{Ca}^{2+}\right]_{\mathrm{c}}$ after and minimal $\left[\mathrm{Ca}^{2+}\right]_{\mathrm{c}}$ before TG treatment for the 160 cells and is shown in $\boldsymbol{C}$. Results represent means \pm SEM. $\boldsymbol{D}$, cells were incubated in the presence of ascorbate $(1 \mathrm{mM})$ and menadione $(10 \mu \mathrm{M})($ Asc/Men $1 / 10)$. At the indicated times, cells were washed twice with PBS and lysed. The relative abundances of P-eIF2 and GRP94 were measured by western blot as described under Section 2. Actin was used as a loading control for each lane. Blots are representative examples of one of 3 independent experiments.

Fig. 6 - ER calcium release potentiates ER stress and cell death caused by Asc/Men. A and $\boldsymbol{B}$, cells were incubated in the presence of ascorbate $(0.5 \mathrm{mM})$ and menadione $(5 \mu \mathrm{M})$ (Asc/Men 0.5/5), $1 \mu \mathrm{M}$ thapsigargin (TG) or both for indicated times. After treatment, cells were washed twice with PBS and lysed. The presence of P-eIF2 and GRP94 (A) or $\gamma$-H2AX $(\boldsymbol{C})$ was measured by western blot as described under Section 2. Actin was used as a loading control for each lane. Blots are representative examples of one of 3 independent experiments. $\boldsymbol{B}$, the effects of Asc/Men and TG on cell survival was monitored by the erythrosine exclusion assay, as described under Section 2. Cells were incubated for different time periods in the absence or presence of the different compounds and non-erythrosine positive cells were counted. All experiments represent means \pm SD of 4 separate experiments. Significant as compared to control, $(*) \mathrm{p}<0.05,(* *) \mathrm{p}<0.01,(* * *) \mathrm{p}<0.001$; significant as compared to TG, (\#) $\mathrm{p}<0.05$, (\#\#) $\mathrm{p}<0.01$; significant as compared to Asc/Men $0.5 / 5$, (†) $\mathrm{p}<0.05)$. 
A

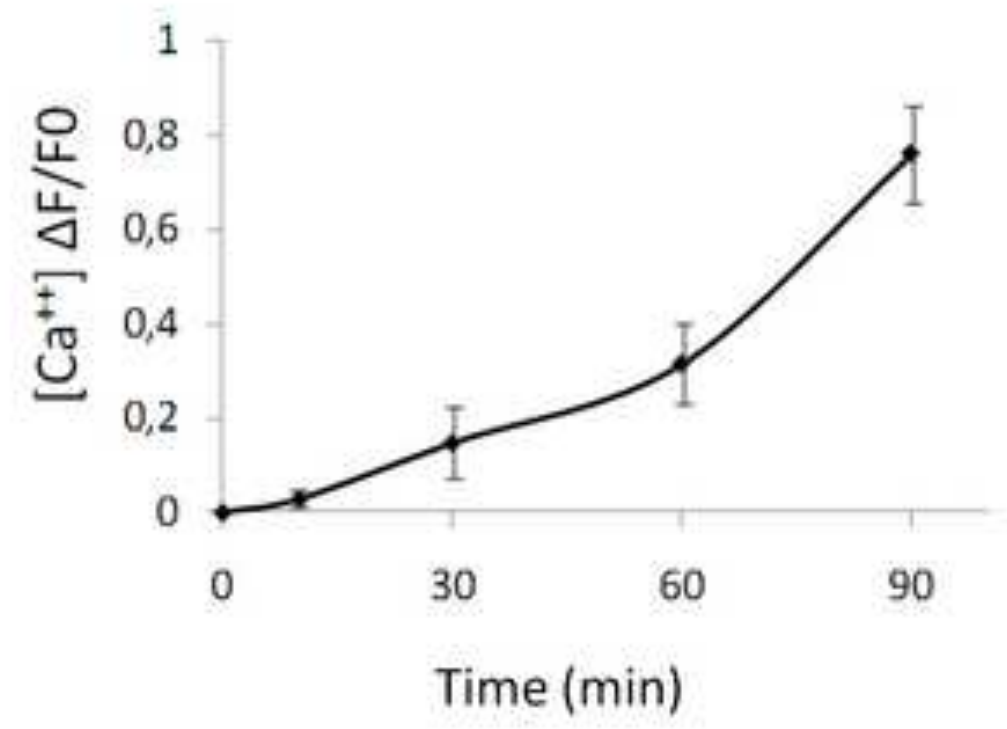

B

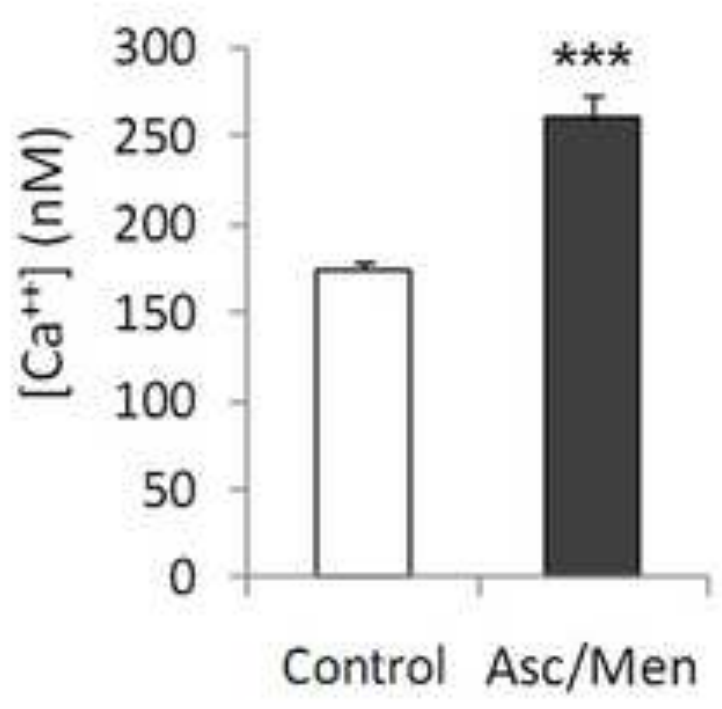

C

Time (min):

30

$60 \quad 90$

180

240

360
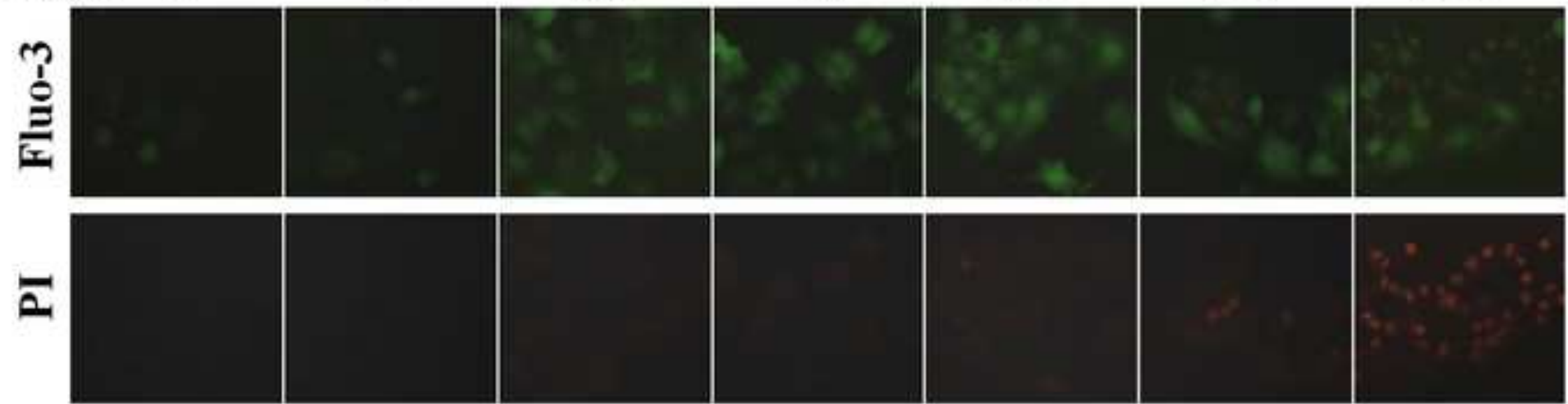

Page 59 of 65 
A

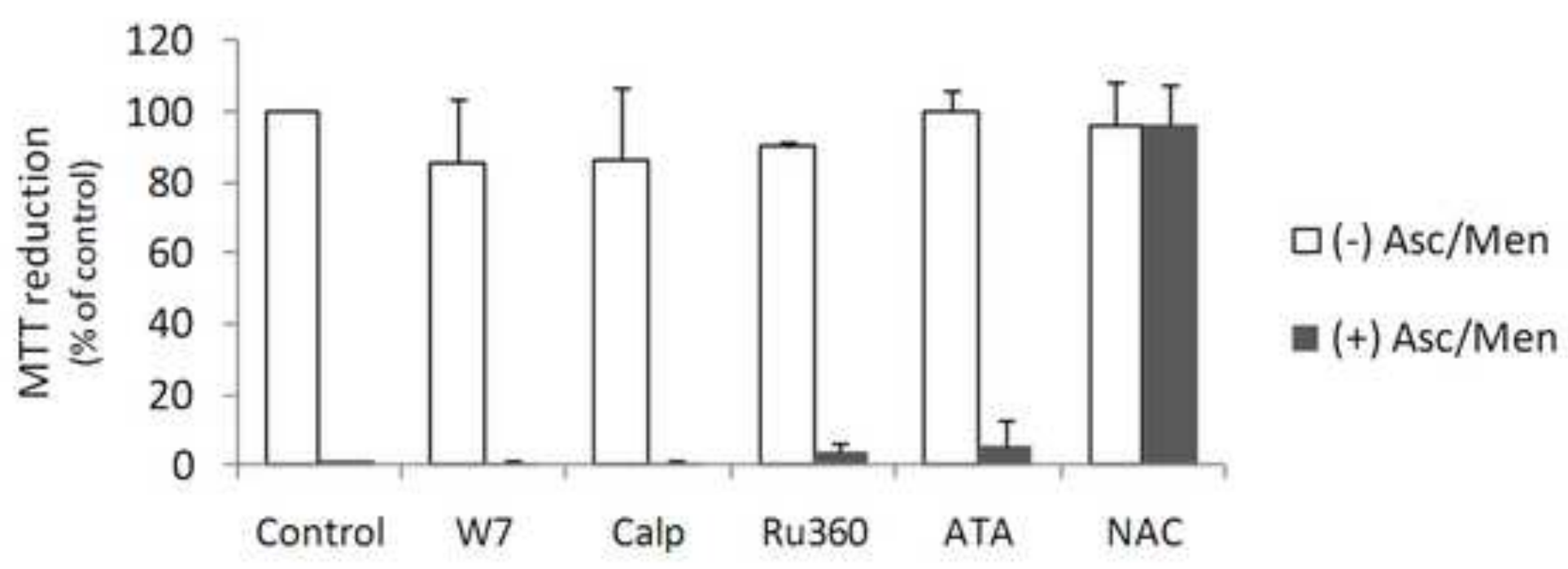

B

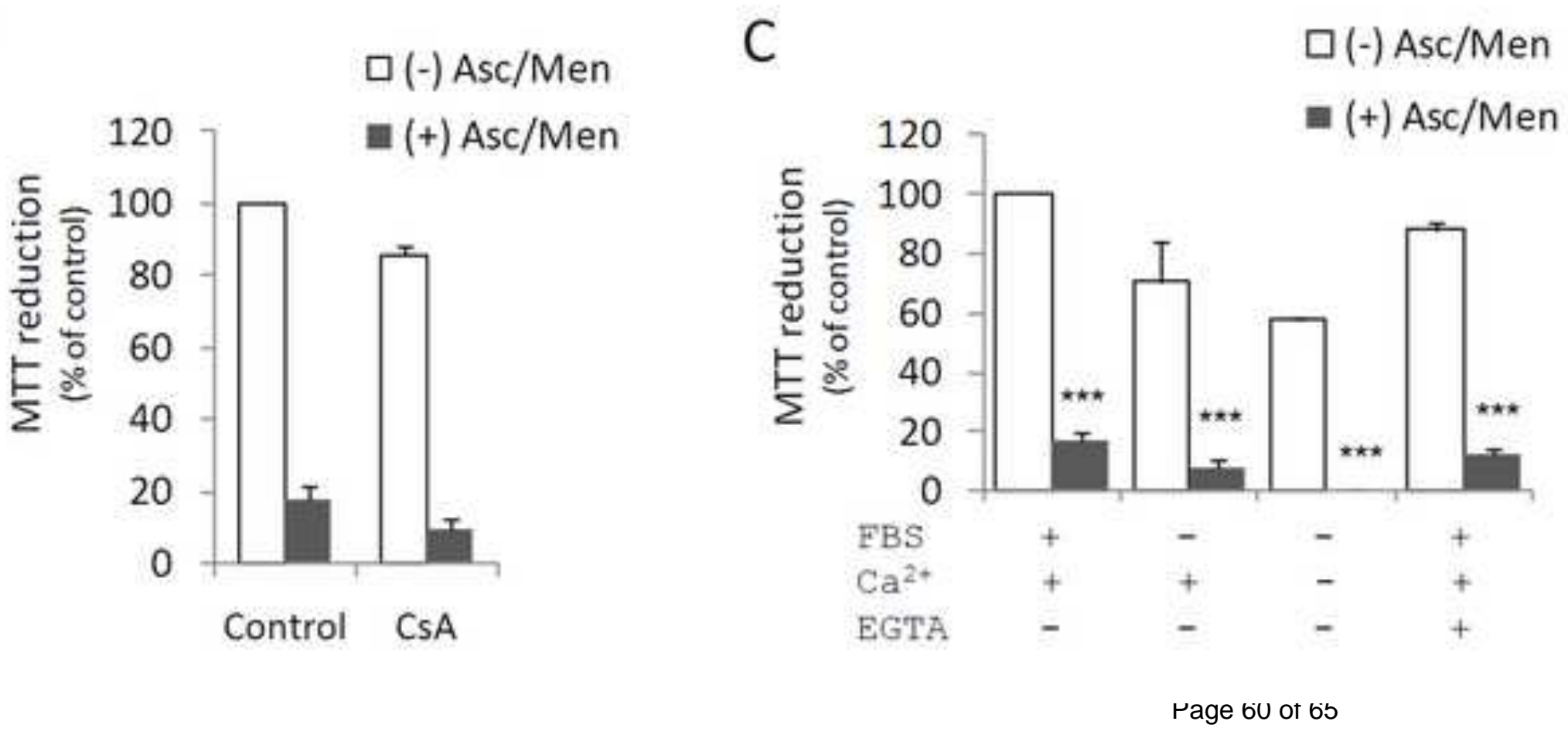


A

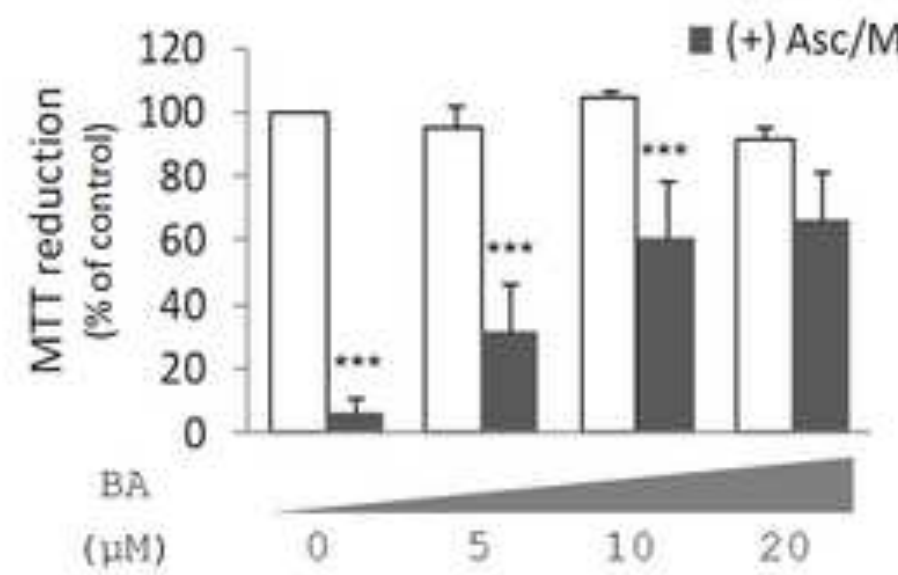

C
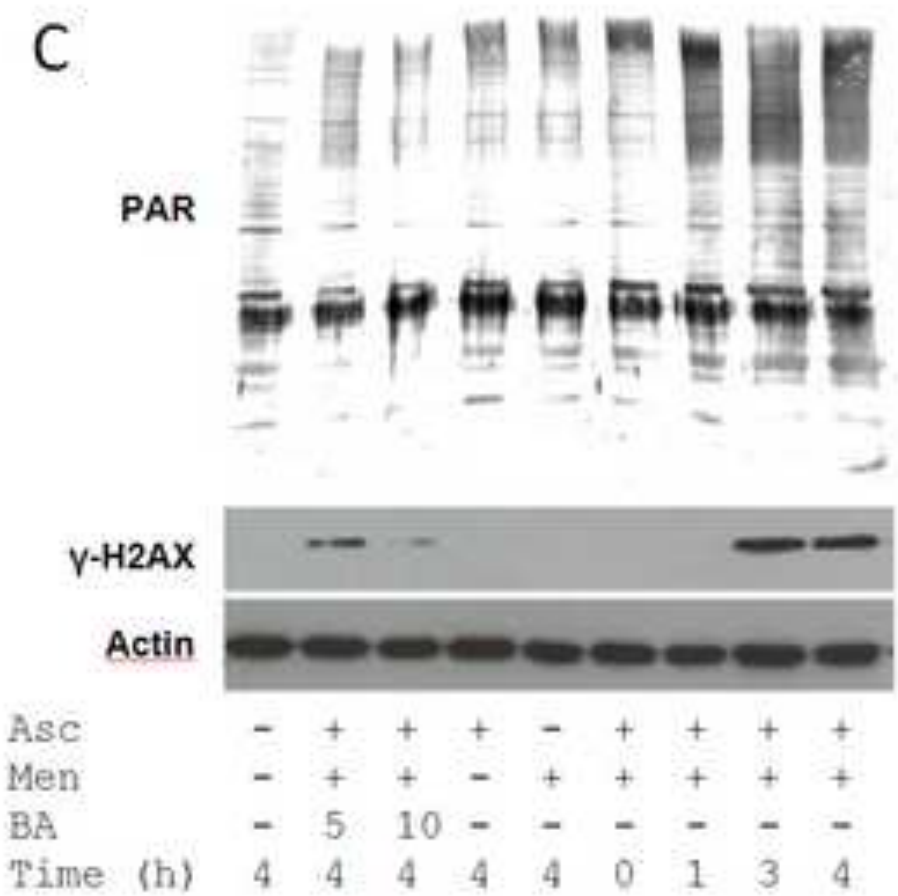

B

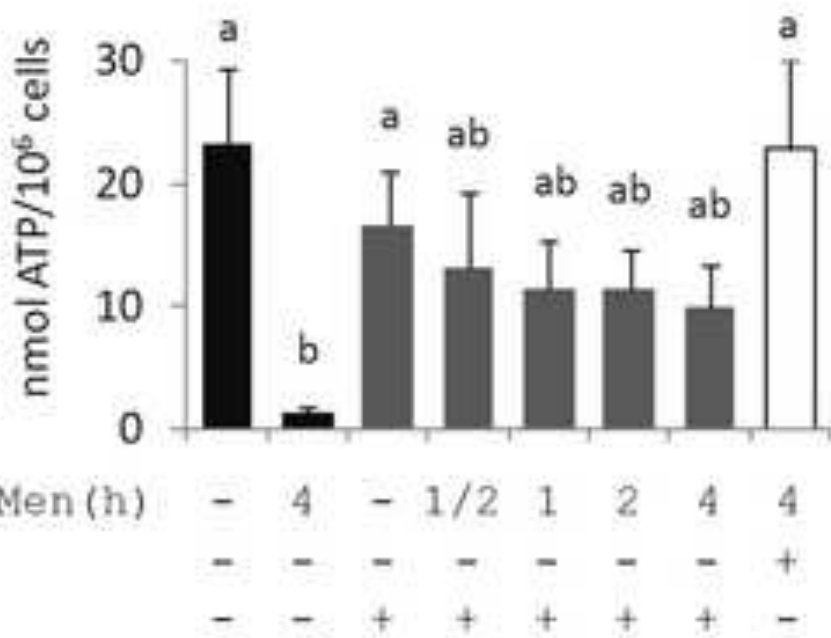

D

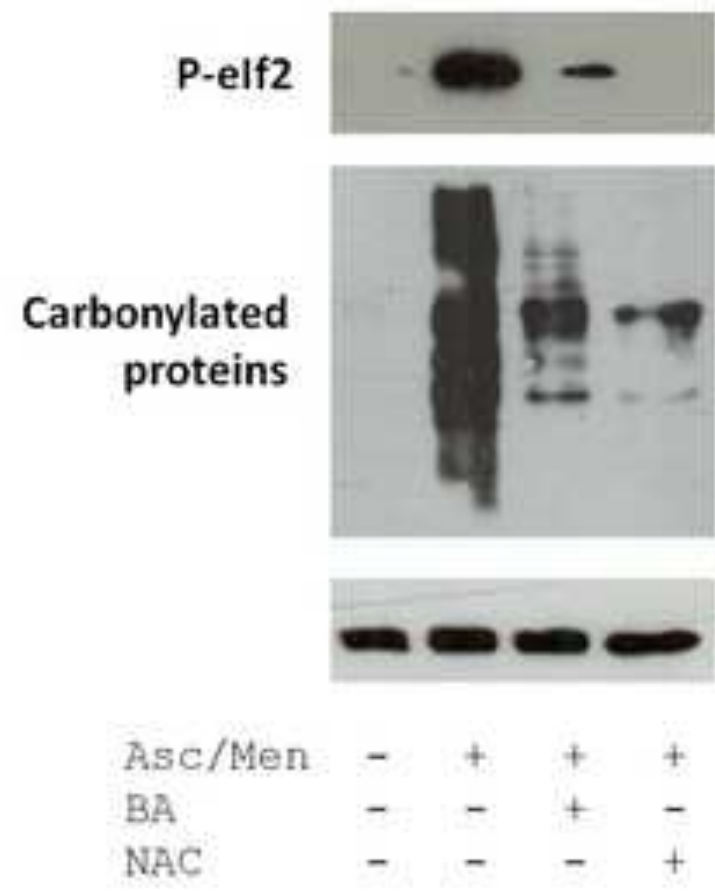


A

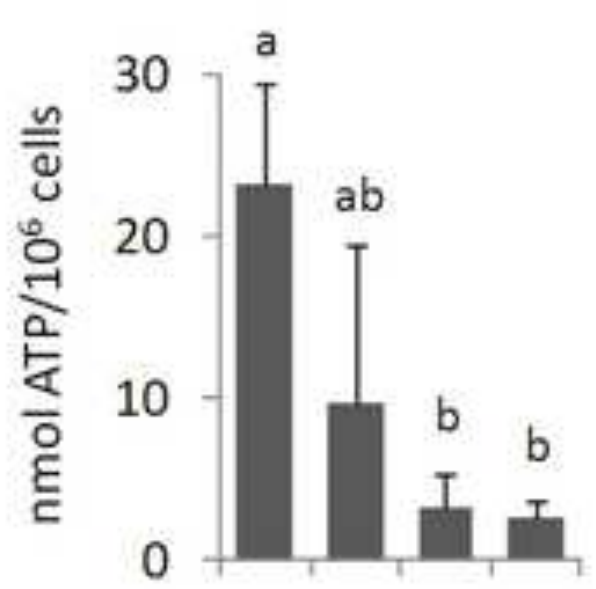

Asc/Men(min) - 3060120

B

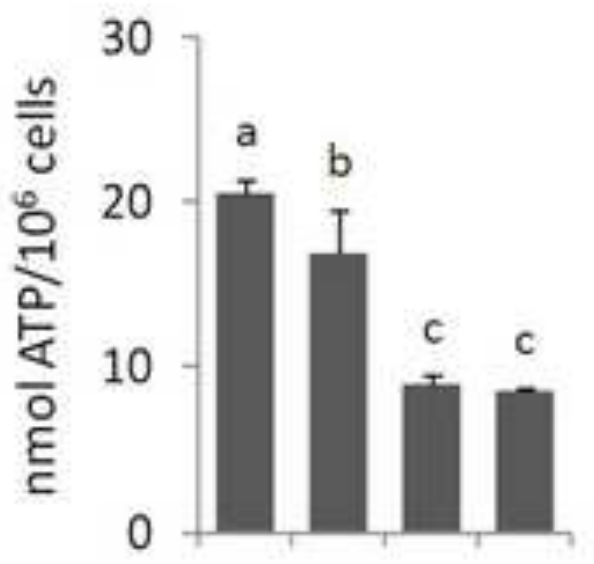

Iodo $(\mathrm{min})$ - 306090

C

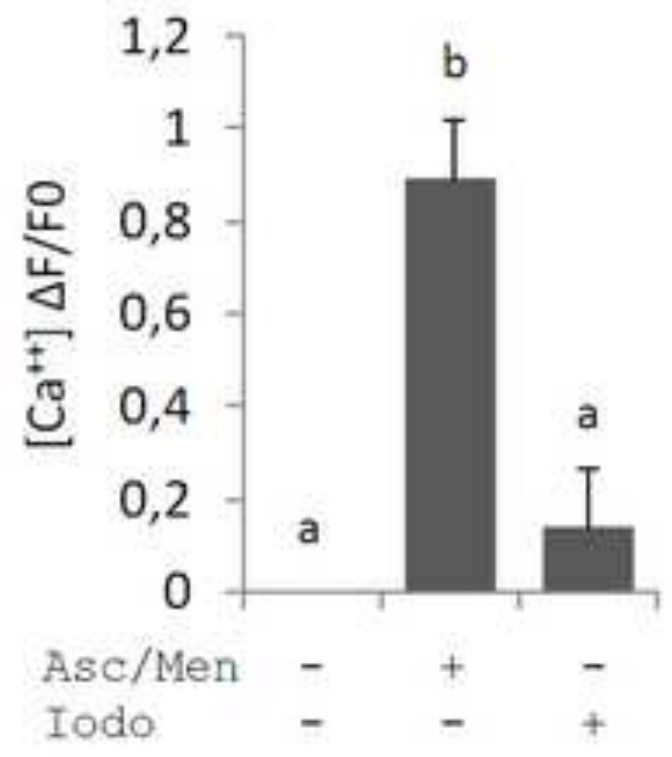


A
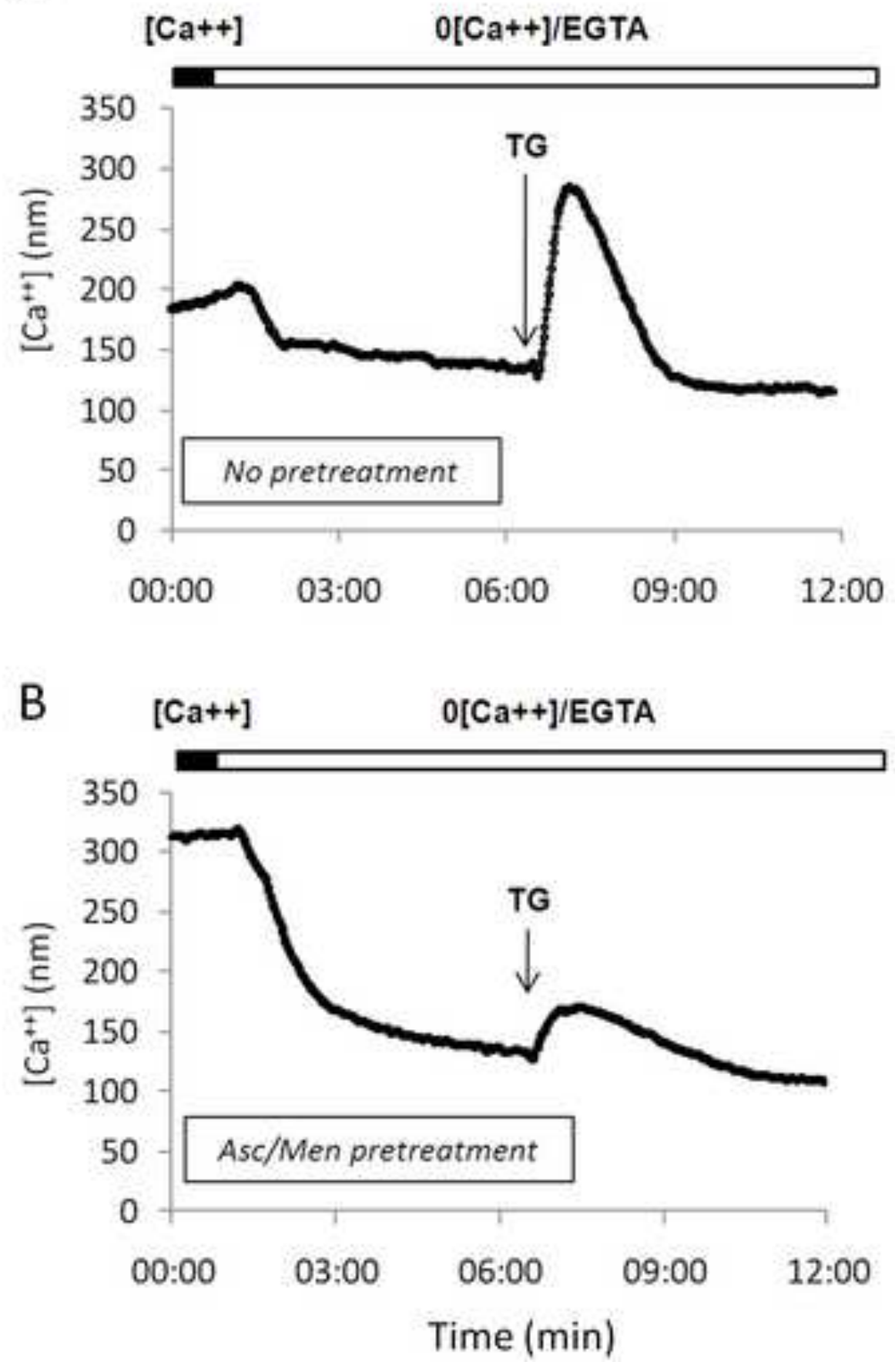

C

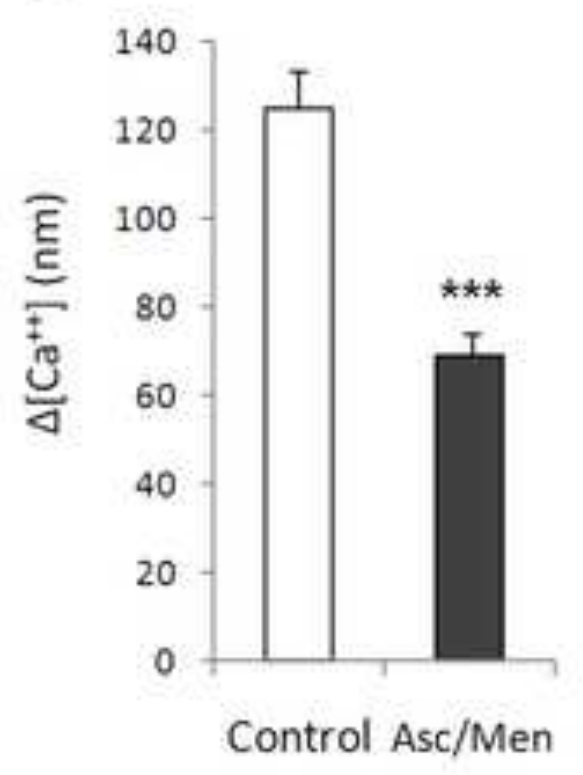

D

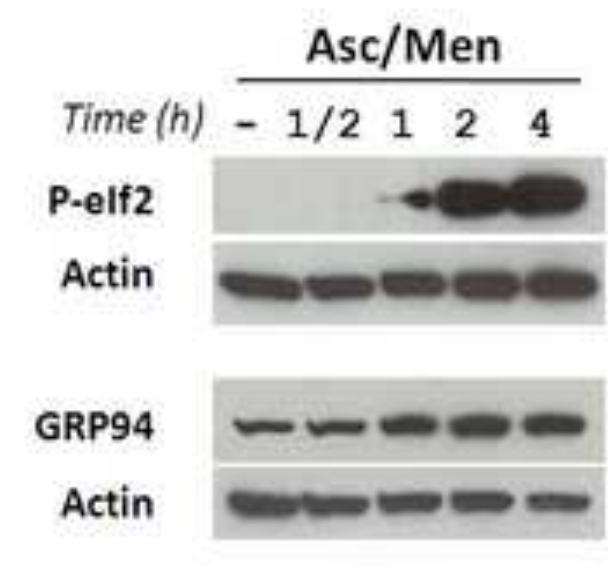

rage bs ot bs

D

rage bos or 
A

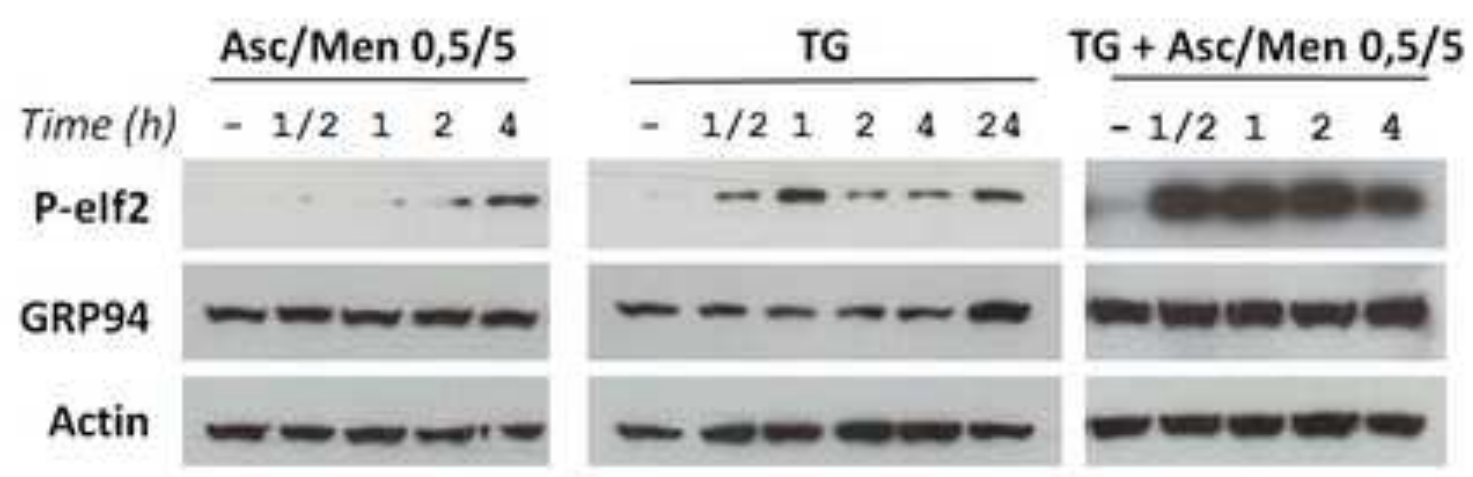

B

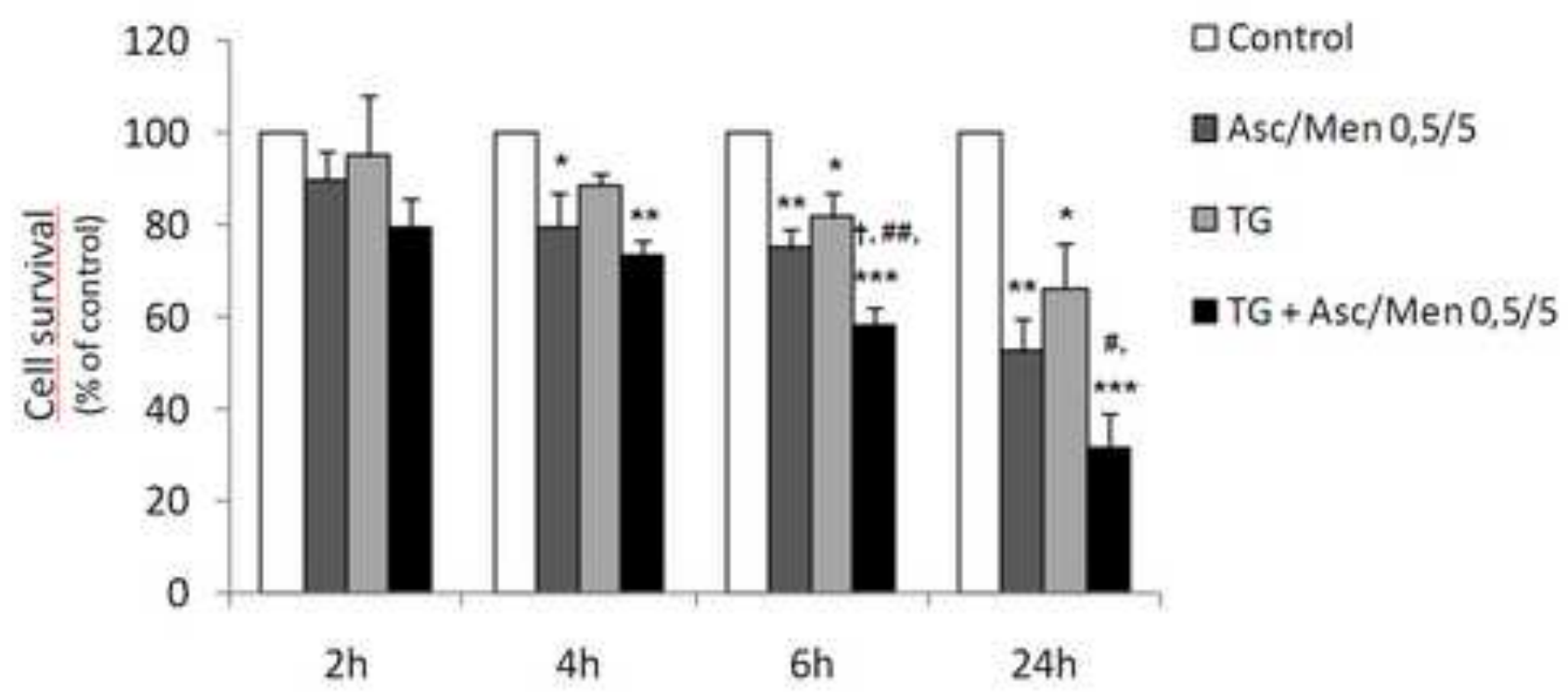

C

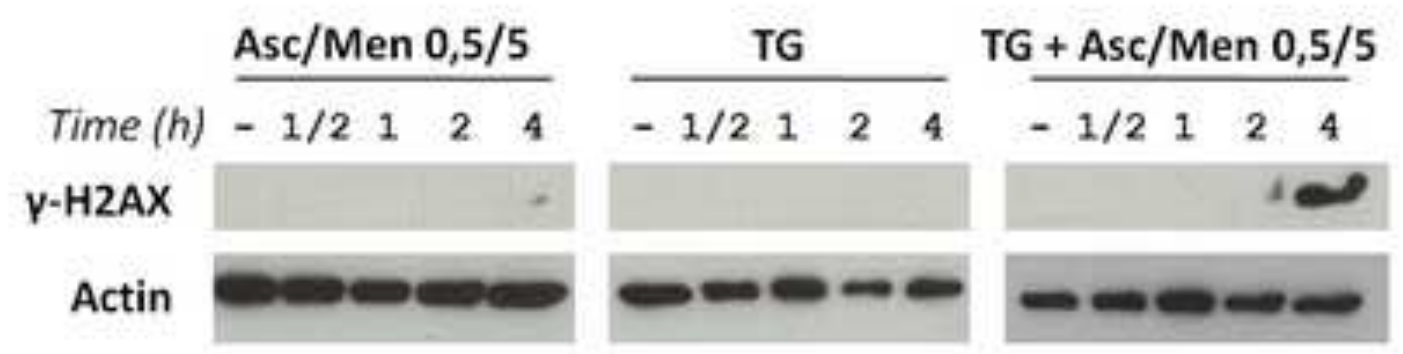




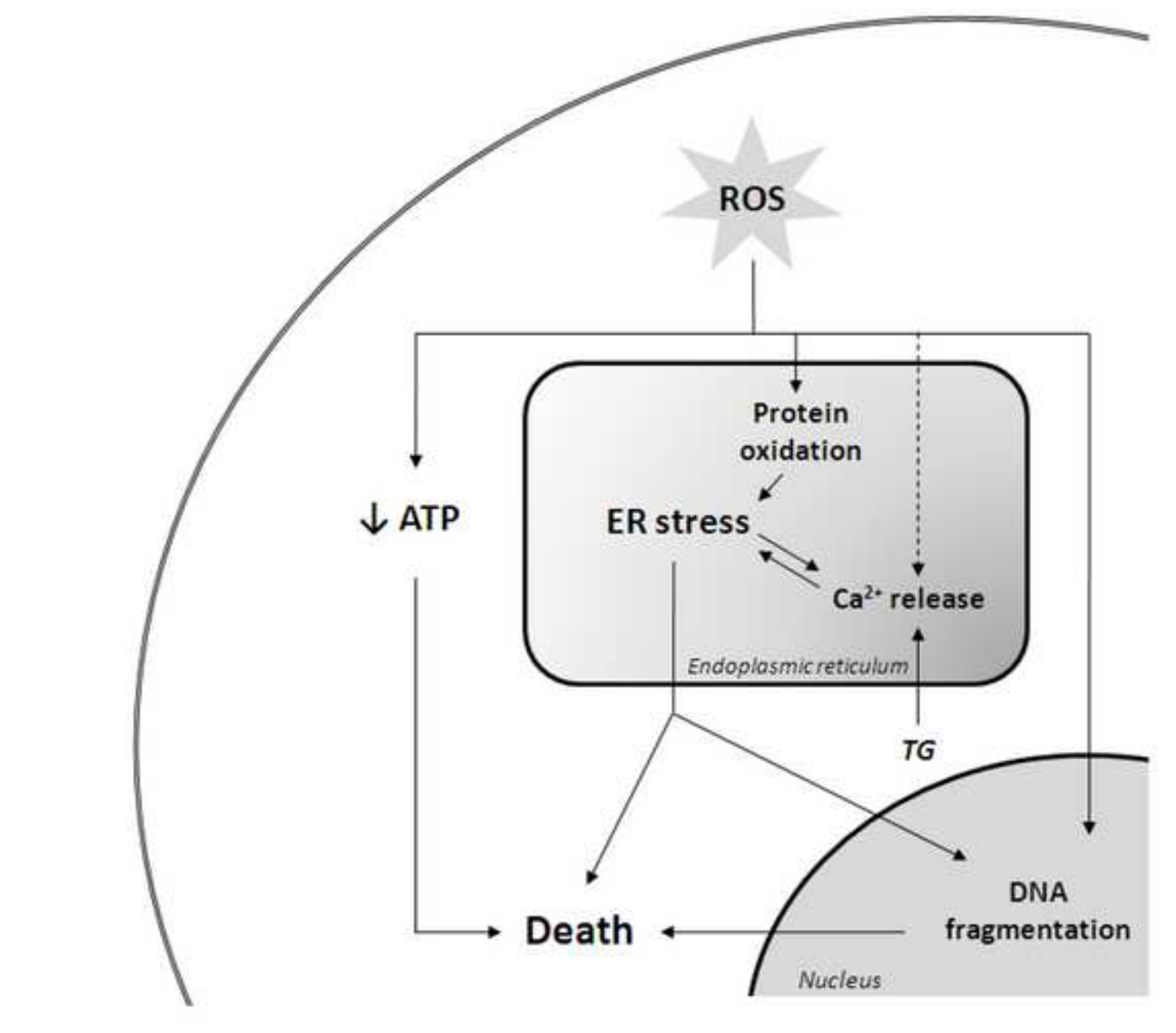

rage bs or bs

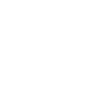

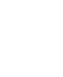

.

\author{
rage bo or bo

